\title{
Mesenchymal stem cells: amazing remedies for bone and cartilage defects
}

\author{
Parisa Kangari ${ }^{1}$, Tahereh Talaei-Khozani ${ }^{1,2}$, Iman Razeghian-Jahromi ${ }^{3}$ and Mahboobeh Razmkhah ${ }^{1,4^{*}}$
}

\begin{abstract}
Skeletal disorders are among the leading debilitating factors affecting millions of people worldwide. The use of stem cells for tissue repair has raised many promises in various medical fields, including skeletal disorders. Mesenchymal stem cells (MSCs) are multipotent stromal cells with mesodermal and neural crest origin. These cells are one of the most attractive candidates in regenerative medicine, and their use could be helpful in repairing and regeneration of skeletal disorders through several mechanisms including homing, angiogenesis, differentiation, and response to inflammatory condition. The most widely studied sources of MSCs are bone marrow (BM), adipose tissue, muscle, umbilical cord (UC), umbilical cord blood (UCB), placenta (PL), Wharton's jelly (WJ), and amniotic fluid. These cells are capable of differentiating into osteoblasts, chondrocytes, adipocytes, and myocytes in vitro. MSCs obtained from various sources have diverse capabilities of secreting many different cytokines, growth factors, and chemokines. It is believed that the salutary effects of MSCs from different sources are not alike in terms of repairing or reformation of injured skeletal tissues. Accordingly, differential identification of MSCs' secretome enables us to make optimal choices in skeletal disorders considering various sources. This review discusses and compares the therapeutic abilities of MSCs from different sources for bone and cartilage diseases.
\end{abstract}

Keywords: Mesenchymal stem cells, Bone, Cartilage, Regeneration

\section{Introduction}

Diseases of skeletal system are extensively widespread in aged population and are considered to be one of the main causes of disability and morbidity [1]. The most common disorders of the skeletal system include intervertebral discs (IVDs), osteoporosis, bone fractures, osteogenesis imperfecta (OI), osteoarthritis (OA), and rheumatoid arthritis (RA) [2] (Table 1). Among various therapeutic approaches for the treatment of these diseases, stem cell therapy seems to be more promising. Stem cells are introduced into tissues to repair, replace, and treat a defect with or without the addition of

\footnotetext{
* Correspondence: razmkhahm@sums.ac.ir; mrazmkhah2@gmail.com 'Department of Tissue Engineering and Applied Cell Sciences, School of Advanced Technologies in Medicine, Shiraz University of Medical Sciences, Shiraz, Iran

${ }^{4}$ Shiraz Institute for Cancer Research, School of Medicine, Shiraz University of Medical Sciences, Shiraz, Iran

Full list of author information is available at the end of the article
}

external gene. The origin of the stem cells can be from autologous or allogeneic sources. They can be used either as naive or primed of the desired lineage [17].

Stem cells are undifferentiated biological entities with the capacity to self-renew and differentiate into specialized cell types. Based on differentiation potential, they are classified as totipotent, pluripotent, multipotent, oligopotent, and finally, unipotent cells [18]. Mesenchymal stem cells (MSCs) are multipotent stromal cells with mesodermal and neural crest origin [19, 20]. They are the most commonly used stem cells in the current preclinical and clinical studies on skeletal diseases [21] (Table 2) either through direct injection or along with scaffolds (a range of natural gels and hydrogels based on collagen, hyaluronic acid (HA), glycosaminoglycans (GAGs), agarose, gelatin and alginate) [37-39] (Fig. 1). These cells are isolated from a variety of tissues like bone marrow (BM), adipose tissue, fetal liver, umbilical 
Table 1 List of the main skeletal diseases, their clinical description and molecular features

\begin{tabular}{|c|c|c|}
\hline Bone diseases & Clinical description & Molecular features \\
\hline $\begin{array}{l}\text { Intervertebral disc (IVD) } \\
\text { degeneration }\end{array}$ & $\begin{array}{l}\text { Increased extracellular matrix breakdown and abnormal } \\
\text { matrix synthesis leading to reduced hydration, loss of } \\
\text { disc height, and decreased ability to absorb load, disc } \\
\text { herniation, vertebral instability and spinal stenosis, back } \\
\text { and neck pain [3] }\end{array}$ & $\begin{array}{l}\text { Collagen I (COL1A1/A2), Collagen IX (COL9A1/A2/A3), } \\
\text { CollagenXI (COL11A1/A2/A3),VDR genes (Taql, Apal), } \\
\text { Col I (COLIA1, Aggrecan (CS1), MMP-3(5A/6A) }[4,5]\end{array}$ \\
\hline Osteoporosis & $\begin{array}{l}\text { Acute back pain caused by a pathologic vertebral } \\
\text { compression fracture as the earliest symptom, decreased } \\
\text { density (mass/volume) of normally mineralized bone, } \\
\text { decreased mechanical strength, making the skeleton } \\
\text { more likely to fracture [6] }\end{array}$ & $\begin{array}{l}\text { Col I (COL1A1/A2), PTH, PTHR, VDR, BMPs (BMP2,4,7, } \\
\text { OP1LRP5), LRP6, RANK, RANKL [7] }\end{array}$ \\
\hline Osteogenesis imperfecta (OI) & $\begin{array}{l}\text { Progressive skeletal deformation, loss of BMD, frequent } \\
\text { fractures, short stature, joint hypermobility and pain }[8,9]\end{array}$ & $\begin{array}{l}\text { mutations in the type I collagen genes COL1A1/A2, } \\
\text { collagen modification (CRTAP, LEPRE1, PPIB), processing } \\
\text { (BMP1), or folding (SERPINH1, FKBP10 }[8,10]\end{array}$ \\
\hline Osteoarthritis (OA) & $\begin{array}{l}\text { Joint inflammation, joint pain, stiffness, swelling and } \\
\text { restriction of joint function [11] }\end{array}$ & $\begin{array}{l}\text { COL2A1, COL9A3, COL11A1, CRTM, VDR, ESR1, BMP5, } \\
\text { ALDH1A2, MCF2L, CHADL, GDF5 and FILIP1, GLIS3, } \\
\text { TGFB1, TNC and WWP2 [12-14] }\end{array}$ \\
\hline Rheumatoid arthritis (RA) & $\begin{array}{l}\text { Joint degeneration, loss of cartilage, and alterations of } \\
\text { subchondral bone, abnormalities of weight-bearing joints } \\
\text { and hands, including knees and hips, symptoms of OA } \\
\text { including pain, stiffness, and altered function in knee } \\
\text { and hips [15] }\end{array}$ & $\begin{array}{l}\text { HLA-DR, PTPN22, IL6R, TRAF1/C5, STAT4, PADI4, FCGR, } \\
\text { CD40, CCL21, CCR6 [16] }\end{array}$ \\
\hline
\end{tabular}

COL collagen, VDR vitamin D receptor, MMP matrix metalloproteinase, PTH parathyroid hormone, PTHR parathyroid hormone receptor, BMP bone morphogenetic protein, $L P R$ low-density lipoprotein receptor-related protein, $R A N K$ receptor activator of nuclear factor kappa $B, R A N K L$ RANK ligand, $B M D$ bone mineral density, CRTM cartilage matrix protein, ESR estrogen receptor, CRTAP cartilage-associated protein, LEPRE1 leucine proline-enriched proteoglycan1, PPIB peptidyl-prolyl isomerase 1 (cyclophylin B), SERPINH1 serpin peptidase inhibitor, clade H, FKBP10 Fk506-binding protein 10, ALDH aldehyde dehydrogenase, MCFL2 MCF.2 cell line derived transforming sequence-like protein, CHADL chondroadherin like, GDF5 growth differentiation factor 5, FILIP1 filamin-A-interacting protein 1, GLIS3 GLIsimilar 3, TGFB1 transforming growth factor beta 1, TNC tenascin C, WWP2 WW domain containing E3 ubiquitin protein ligase 2, HLA-DR human leukocyte antigen - DR isotype, PTPN22 protein tyrosine phosphatase, non-receptor type 22, IL6R interleukin-6 receptor, TRAF1/C5 tumor necrosis factor receptor-associated factor-1, STAT4 signal transducer and activator of transcription 4, PADI4 peptidylarginine deiminase 4, FCGR FC gamma receptor, CCL21 CC chemokine ligand $21, C C R 6$ CC chemokine receptor 6

cord (UC), muscle, endometrial polyps, dental tissue, synovial fluid, skin, foreskin, Wharton's jelly (WJ), placenta, dental pulp (DP), breast milk, gingiva, amnion, and menstrual blood [40-54]. MSCs are characterized as plastic adherent cells with fibroblastic morphology in culture. These cells lack the expression of hematopoietic markers such as CD45, CD34, and CD14, but express mesenchymal specific markers including CD73, CD90, and CD105 [55]. A list of positive and negative markers on MSCs from various sources is presented in Table 3. Human MSCs (hMSCs) usually express low levels of MHC class I, with no expression of MHC class II [64]. These cells demonstrate three distinct biological characteristics (potential of differentiation, secretion of trophic factors and immunoregulatory properties) which make them an excellent candidate for cell therapy [65]. MSCs possess the capacity to differentiate into a wide variety of cell types including adipocytes, osteoblasts, chondrocytes, and myocytes. Also, they are capable of transdifferentiating into ectodermal lineages such as neuronal cells and endodermal lineages such as hepatocytes and pancreatic islet cells $[39,65,66]$. MSCs are of great importance because of their paracrine effects through secreting growth factors and cytokines, such as vascular endothelial growth factor (VEGF), transforming growth factor beta (TGF- $\beta$ ), and interleukins (IL-1 $\beta$,
IL-6, and IL-8) [67]. Moreover, MSCs have an additional ability to modulate immune responses through repressing $\mathrm{T}$ cell proliferation, dendritic cell (DC) maturation, B cell activation, and cytotoxic activation of resting NK cells [68-73].

\section{Bone structure}

As the main part of the skeletal system, the bone contributes to the locomotion, soft tissue protection, harboring of BM, blood production, progenitor cell (mesenchymal and hematopoietic) housing, regulation of blood $\mathrm{pH}$ and maintenance of calcium, and phosphate homeostasis [74, 75]. Macroscopic examinations show that bone tissue is a heterogeneous and porous structure comprising two bone types including cortical (compact) and cancellous (spongy). Comparison of cortical and cancellous bones reveals significant different masses, so that the former has major mass-to-volume ratio [76, 77]. Owing to be a dynamic connective tissue, the bone has cells and extracellular matrix (ECM) which consists of organic and inorganic phases. Collagen fibers are the main makeup in the organic phase while inorganic phase is mainly composed of hydroxyapatite [76, 78, 79]. The cellular components are osteoprogenitors, osteoblasts, bone lining cells, osteocytes, and osteoclasts. Osteoblasts are one of the most important differentiated cells in the 
Table 2 Preclinical and clinical studies of MSCs for the treatment of skeletal diseases

\begin{tabular}{|c|c|c|c|}
\hline Defect type & Model & MSC type & Findings \\
\hline \multirow[t]{4}{*}{ IVD } & Porcine & Autologous BM-MSCs & $\begin{array}{l}\text { Reduction in COL1 expression as a marker for fibrosis, reduction of inflammation } \\
\text { marker ILI } \beta \text { and elevation of trophic factor BMP2, reducing disc degeneration [22] }\end{array}$ \\
\hline & Rat & Xenogeneic hAD-MSCs & $\begin{array}{l}\text { Viability and proliferative potentiate of AD-MSC transplanted within the rat IVD, } \\
\text { contribution in the maintenance of disc height after the operation [23] }\end{array}$ \\
\hline & Human $(n=5)$ & Autologous BM-MSCs & Improvement in strength and mobility post stem cell treatment [24] \\
\hline & Human $(n=10)$ & Autologous BM-MSCs & $\begin{array}{l}\text { Feasible and safe, rapid improvement of pain and disability (85\% of maximum in } \\
3 \text { months) [25] }\end{array}$ \\
\hline \multirow[t]{2}{*}{ Osteoporosis } & Goat & Autologous BM-MSCs & Improvement of bone formation in the osteoporotic model in vivo [26] \\
\hline & Rat & Xenogeneic hUCB-MSCS & $\begin{array}{l}\text { Enhancement of bone formation abilities in osteoporotic rat model similar to no } \\
\text { osteoporotic bone regeneration [27] }\end{array}$ \\
\hline \multirow[t]{2}{*}{ Ol } & Mouse & Human fetal e-CSCs & $\begin{array}{l}\text { Reduction of fractures, increasing bone ductility and BV by directly differentiating to } \\
\text { osteoblasts, stimulating host chondrogenesis and osteogenesis [28] }\end{array}$ \\
\hline & Human $(n=3)$ & Allogeneic BM-MSCS & Increase in total body bone mineral content and new dense bone formation [29] \\
\hline \multirow[t]{3}{*}{ Bone fractures } & Rabbit & Autologous AD-MSCs & $\begin{array}{l}\text { Improvement of healing process in tibial defects compared to using hydroxyapatite } \\
\text { alone [30] }\end{array}$ \\
\hline & Rat & Xenogeneic hDP-MSCs & $\begin{array}{l}\text { Increased callus homogeneity, decline callus earlier size, increased percentage of } \\
\text { lamellar in newly formed bone, lower incidence of fibrous tissue in the experimental } \\
\text { group, advanced and more efficient bone healing in the cell-treated group compared } \\
\text { to the control [31] }\end{array}$ \\
\hline & Human $(n=18)$ & $B M A C$ & $\begin{array}{l}\text { Faster healing in BMAC cancellous bone allograft transplanted group compared to an } \\
\text { autologous bone graft, efficacy of BMAC for treatment of nonunion [32] }\end{array}$ \\
\hline \multirow[t]{4}{*}{$\mathrm{OA}$} & Rat & Allogeneic BM-MSCS & $\begin{array}{l}\text { Chondroprotection and reduced subchondral bone mineral density in the } \\
\text { transplantation [33] }\end{array}$ \\
\hline & Human $(n=4)$ & Autologous BM-MSCs & $\begin{array}{l}\text { Positive changes in all patients, clear bone formation in osteonecrosis patients, } \\
\text { cartilage regeneration in the OA patients [34] }\end{array}$ \\
\hline & Human $(n=6)$ & Autologous BM-MSCs & $\begin{array}{l}\text { Improvement of pain, functional status of the knee and walking distance, increase in } \\
\text { cartilage thickness, extension of the repair tissue and a considerable decrease in the } \\
\text { size of edematous subchondral patches [35] }\end{array}$ \\
\hline & Human $(n=18)$ & Autologous AD-MSCs & $\begin{array}{l}\text { Reduced cartilage defects by regeneration of hyaline-like articular cartilage and } \\
\text { improvement of function and pain of the knee joint without causing adverse } \\
\text { events [36] }\end{array}$ \\
\hline
\end{tabular}

IVD intervertebral disc, BM-MSCs bone marrow-derived mesenchymal stem cells, COL1 collagen typ1, IL $1 \beta$ interleukin1 $\beta, B M P 2$ bone morphogenetic protein, hAD-MSCs human adipose-derived mesenchymal stem cells, hUCB-MSCs human umbilical cord blood-derived mesenchymal stem cells, OI osteogenesis imperfecta, $e$-CSCs human fetal early chorionic stem cells, $B V$ bone volume, $B M A C$ bone marrow aspiration concentrate, $O A$ osteoarthritis, $h D P-M C s$ human dental pulp-derived mesenchymal stem cells

bone originating from bone marrow mesenchymal stem cells (BM-MSCs). Osteoblasts play critical roles in the synthesis of ECM components including type I collagen, proteoglycans, and non-collagenous proteins and also participate in matrix mineralization and blood-calcium homeostasis. Osteocytes, as the most abundant and long-lived cells, are the mature trapped osteoblasts in the lacunae. Osteoclasts are large multinucleated cells that originate from mononuclear cells and participate in the absorption of bone, calcium and phosphate excretion, bone healing, and remodeling [78, 80-83].

Bone diseases are one of the most common body injuries, and are associated with high health expenses exceeding billions of dollars annually [84]. Prevalence of such defects is increasing; thereby, they are considered an epidemic health challenge [85]. The bone benefits from the ability to repair itself throughout the life. Bone regeneration is a process in which osteoclasts and osteoblasts are tightly involved [80]. Despite spontaneous regeneration potential, there are several different reasons such as bone defect size and infection that cause damaged bone not to be able to restore itself [86]. In the following sections, common approaches and new therapies in restoring and treating bone defects will be discussed.

\section{Bone diseases and MSC therapy \\ Intervertebral disc (IVD) degeneration}

Intervertebral discs (IVDs) are circular pieces of gelly fibrocartilage tissue between vertebral of the spine functioning for shock-absorption. They are the reason of flexibility in the neck and lumbar regions and thus contribute to motion. Anatomically, they have three important substructures: nucleus pulposus (NP), anulus fibrosus (AF), and cartilaginous end plates (CEPs) [8789]. One of the highest risk factors for disc degeneration is aging [90]. As age increases, cellular and structural changes in NP, AF, and CEP lead to IVD [91]. Findings showed that IVD alterations during aging start cleft 

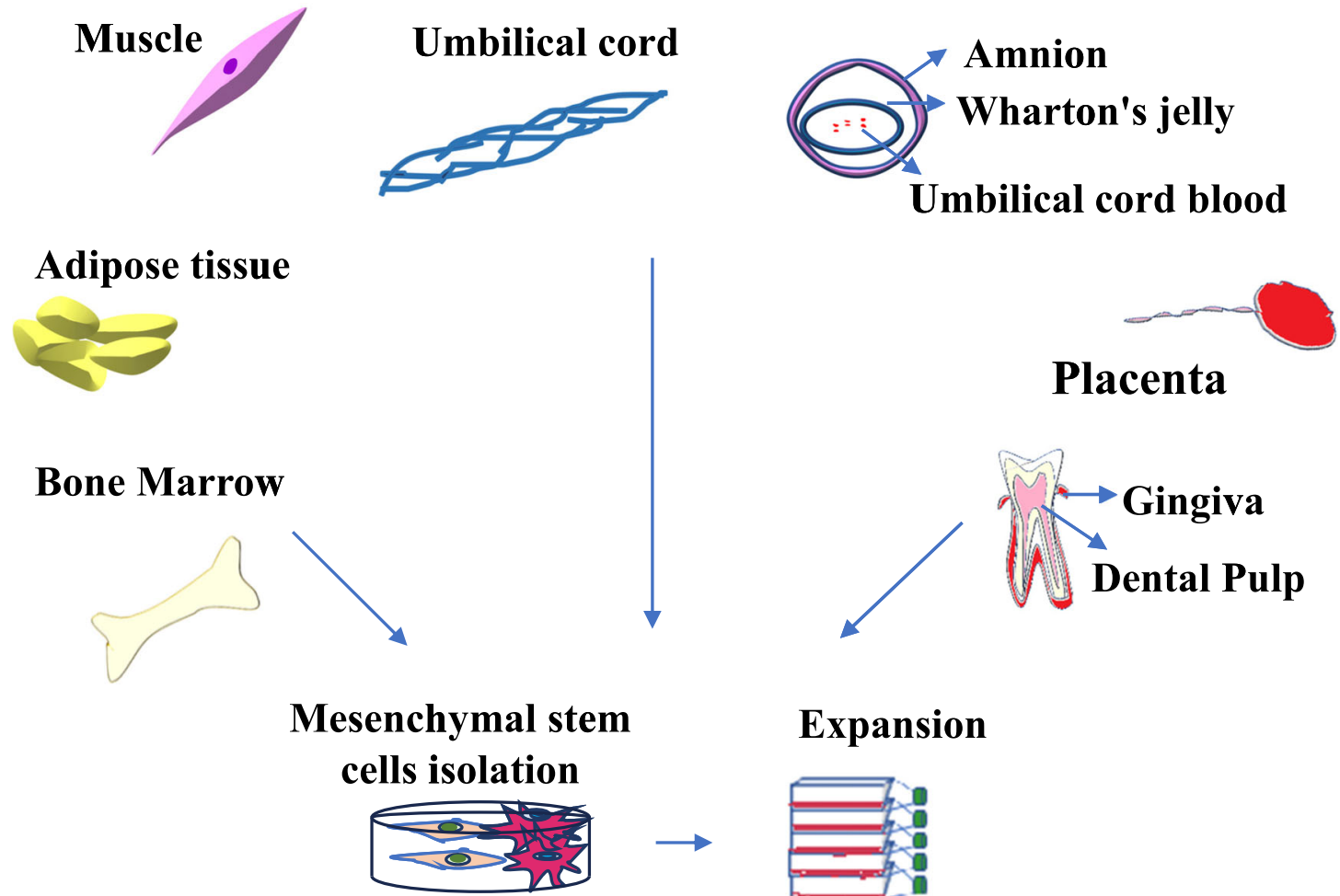

Expansion

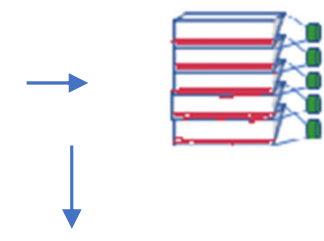

Mesenchymal stem cells

\section{Cartilage}

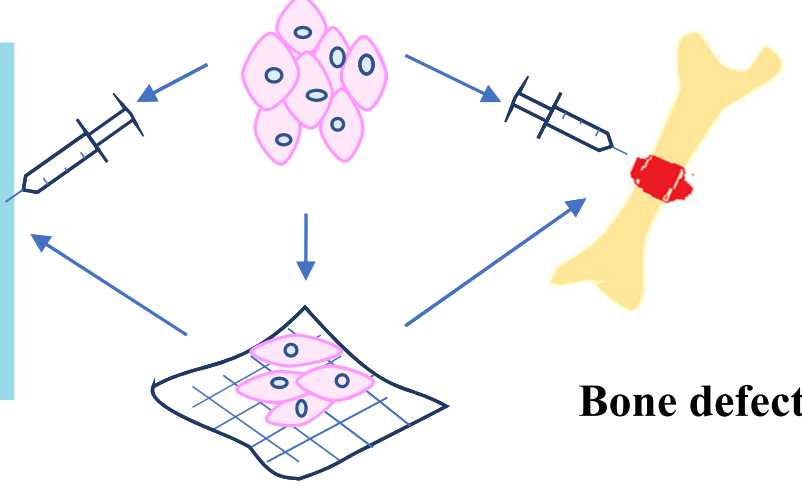

\section{Scaffold}

Fig. 1 Mesenchymal stem cell (MSC) sources and applications. MSCs are originated from various sources such as bone marrow, adipose tissue, placenta, umbilical cord, Wharton's jelly, muscle, and dental tissues. They may be used either by loading within scaffold or as cell suspensions for regenerative purposes including cartilage and bone defects

formation in NP [92]. Meanwhile, AF becomes disorganized, stiffer, and weaker [93].

One of the main symptoms of disk degeneration is back and neck pain which can terminate into several disabilities [93]. Treatment approaches for degenerative disc disease (DDD) are physiotherapy, pharmacotherapy, and surgery. However, they are only pain-relieving strategies in most cases and do not eliminate the underlying reason or restore the lost functions. Therefore, researchers are looking for novel therapeutics in order to regenerate DDD $[88,94,95]$. The best defining characteristics of DDD are the accumulation of senescent cells as well as reduction in the number of functional cells [95]. Several in vitro and in vivo studies on the degeneration of the IVD both in animal models and in clinical trials indicated that NP, AF, and CEPs contain cells with surface markers, morphology, proliferation rate, and multilineage differentiation capability similar to 
Table $\mathbf{3}$ Characterization of MSC from various tissues based on surface markers

\begin{tabular}{lll}
\hline Tissue & Positive markers & Negative markers \\
\hline Bone marrow & CD29, CD31, CD44, CD49a, CD49b, CD49C, CD49d, CD49e, CD51, CD54, & CD11a, CD11b, CD13, CD14, CD19,CD34, CD45, \\
& CD58, CD61, CD71, CD73, CD90, CD102, CD104, CD105, CD106, CD120a, & CD133 [56] \\
& CD120b, CD121a, CD124, CD146, CD166, CD221, CD271, SSEA-4, & \\
Adipose tissue & STRO-1 [56] & \\
Synovial fluid & CD9, CD10, CD13, CD44, CD54, CD55, CD90, CD105, CD166, D7-FIB, CD49a, & CD14, CD45, CD34, CD117, CD62e, CD20, CD113, \\
& CD147, CD73, PDGFRa (CD140a) [59] & HLA-DR, CD68, CD31, ALP [59] \\
Dental pulp & CD29, CD44, CD105, CD146, CD117 and STRO-1 [60], SSEA-4, CD146, CD73, & HLA-DR, CD106, CD34,CD7,CD31 [61] \\
& CD44, CD10, CD123 [61] & \\
Amnion & CD73, CD29, CD49f, Oct4, Nanog, Sox2, SSEA-3, SSEA-4, Rex1 [62] & CD14, CD20, CD34, CD45 [63] \\
\hline
\end{tabular}

stem cells. This evidence suggests that IVDs possess stem cells that may provide cell candidates for cell-based regenerative medicine and tissue engineering [96-100]. On the other hand, studies on human degenerative IVD tissue demonstrated the existence of progenitor cells similar to BM-MSCs. As an endogenous source, they can be activated in situ after exposure to some growth factors involved in the repair of degenerative IVD [101, 102]. Regeneration is aimed to replace damaged with new functional cells that can be supplied by resident stem cells proliferation or division of differentiated cells. Therefore, these cells should be infiltrated into the tissue following by exposure to the growth factors until enabling to reconstruct lost structures [103-105]. Despite avascular nature of the IVD, it has been demonstrated that stem cells are capable of migrating from their niche throughout the body toward all three IVD constituent layers and they have more tendency to home at the vascular tissues such as CEPs and outer layer of AF [106-108]. Due to the absence of the active cell population in IVD, it needs to introduce stem cells in IVD for tissue regeneration. Findings from several preclinical and clinical studies demonstrated that MSCs are attractive candidates for regeneration of diseased disk [25, 109111]. These cells should be isolated from an appropriate tissue and expanded in vitro and then, either intact or manipulated, implanted in the injured site [37, 112114]. Multiple factors should be considered for choosing the appropriate cell source such as abundance, ease of obtaining, the capacity to differentiate into NP and AF cells, cell viability under hypoxic condition, cell viability under hypoglycemic condition, and non-tumorigenicity [109]. The investigations showed that scaffolds are capable of inducing MSC differentiation into a chondrogenic lineage such as NP-like cells under hypoxic or physiological conditions [115-117]. In an ex vivo study on degenerative IVD of bovine origin, it is demonstrated that human BM-MSCs (hBM-MSC) have immunomodulatory and anti-inflammatory effects through reduction of pro-inflammatory cytokines such as IL-6, IL-8, and tumor necrosis factor alpha (TNF- $\alpha)$ [118]. Transplantation of autologous BM-MSCs in a porcine model led to the elevation of trophic factor, bone morphogenetic protein-2 (BMP-2) in the NP, whereas the inflammation marker, IL-1 3 , was reduced in the AF [22]. On the other hand, Sun and co-workers, in an in vitro study first showed the impact of adipose-derived mesenchymal stem cells (AD-MSCs) for protecting human NP cells, through inhibiting caspase- 9 and caspase- 3 activity. Also, they revealed the suppression of pro-inflammatory factors, thereby preventing apoptosis and degeneration of NP cells. It was concluded that AD-MSCs may be a promising treatment strategy for DDD [119]. Recently, numerous clinical trials on regeneration of disk disease by MSC therapy are ongoing [25, 120, 121]. Yoshikawa et al. explored the role of autologous BM-MSCs in 2 patients with low back pain, leg pain, and numbness. They observed improvement of pain and disability during 3 months beside augmentation of hydration within one year after MSCs injection [121]. In addition to BMMSCs and AD-MSCs [122-124], there are other major cell sources used for DDD regeneration including muscle-derived stem cells (MdSCs) [125], olfactory membrane stem cells [126], and synovial stem cells [127]. However, AD-MSCs and BM-MSCs are common sources for IVD regenerative therapy and BM-MSCs are widely applicable in human trials.

\section{Osteoporosis}

Osteoporosis, as a systematic skeletal disorder, is a common age-related bone defect which affects women more than men. Osteoporosis cause bone mineral density (BMD) loss and the degradation of the bone microstructure due to an abnormal imbalance between bone formation by osteoblasts and bone resorption by osteoclasts $[128,129]$. Additionally, MSCs population in the BM are declined with aging; thus, their function will be limited and they cannot contribute to bone formation any longer [130]. Osteoporosis is of great importance mostly because of its effect on bone fragility. It also causes back 
pain and decreased quality of life which are collectively associated to high economic burden. Accordingly, suitable treatment strategies are essential for preventing disease and improving quality of life [131, 132]. Current osteoporosis treatments are principally using drug-based agents that usually stimulate apoptosis in osteoclasts and prevent the bone resorption [133]. However, they are associated with some side effects and therefore do not provide patient satisfaction [134-138].

During the last decade, stem cell therapy, as a new technology, is widely developed for bone regeneration in patients with osteoporosis. MSCs are the most extensively used stem cell type for this disease [128]. Studies in animal models have revealed that both allogeneic and autologous BM-MSCs transplantation are applicable for the treatment of osteoporosis [26, 139-142]. Allogeneic BM-MSCs therapy in glucocorticoid-induced osteoporosis in mice models showed osteoblastogenesis and promoted bone formation [143]. In a clinical trial by Lozano-Rivas and co-workers on new osteoporotic fractures, reduced pain was seen in patients with osteoporosis following autologous intravenous (IV) infusion of fucosylated BM-MSCs [144]. MSCs from perinatal tissues like human umbilical cord (hUC), human umbilical cord blood (hUCB), amnion, and chorion, have attracted special attention for osteoporosis improvement and preventing bone loss [145-147]. Recently, ovariectomyinduced osteoporosis was established in the rats along with reduction in estradiol level, bone mass, and collagen content. These rats received definitive number of human umbilical cord-derived mesenchymal stem cells (hUC-MSCs) and showed higher bone mass, collagen content, and osteoblasts number, while the number of osteoclasts decreased in the hUC-MSCs implantation site. Also, an in vitro study confirmed that hUC-MSCs promote osteoblasts formation while preventing the cellular activity of osteoclasts. This research showed that transplanted hUC-MSCs in the injured site in ovariectomized rats are capable of differentiating to osteoblasts and elevating collagen and osteocalcin levels as the main bone markers [148]. Hendrijantini and co-workers observed increase in the number of osteoblasts and overexpression of both TGF- $\beta 1$ and runt-related transcription factor 2 (Runx2) after injection of hUC-MSCs in osteoporotic rat models [149]. Increased expression of TGF$\beta 1$ contributes to MSCs mobilization to the defect site, osteoblast differentiation, and ultimately bone formation $[150,151]$. The osteogenic transcription factor, Runx2, prevents MSC differentiation into the other lineages except osteoblasts and enhances osteocalcin expression as a bone formation marker $[151,152]$. These findings provide a new therapeutic strategy and demonstrate that hUC-MSCs can clinically resolve bone-related medical conditions such as osteoporosis.
AD-MSCs are more abundant and easily available in comparison with BM-MSCs. Indeed, their number is not affected by age making them more applicable in cell based therapeutics and tissue repair like osteoporotic bone regeneration [153, 154]. Comparing systemic injection of osteoporotic donor-derived AD-MSCs and BM-MSCs to ovariectomized mice indicated that ADMSCs retained their anti-inflammatory potential and caused the maintenance of bone homeostasis in recipients with osteoporosis. AD-MSCs but not BM-MSCs showed the ability to resist in damaged microenvironment and maintain many properties including stemness and regulation of $\mathrm{T}$ cell viability. These results may show the priority of AD-MSCs over BM-MSCs for osteoporotic cytotherapy [155]. Oommen and co-workers suggested that AD-MSCs are useful treatment options for osteoporosis since these cells caused osteogenic induction by osteoblast differentiation and osteoid formation in ovariectomized rats [156]. In another study, Saito and his colleagues observed that autologous transplantation of BM-MSCs derived from osteoporotic rat models was associated with decreased osteoclast proliferation and mobilization, while adding UC extract improved the functionality of BM-MSCs regarding excessive osteolytic properties of osteoclasts [146]. Although BM-MSCs play key roles in maintaining bone metabolism, homeostasis, bone repair, and homing after systemic injection, their regenerative ability may be weak in the case of patients with postmenopausal osteoporosis [146, 157, 158]. Comparative study between different hMSCs sources including BM, AT, WJ, and placenta (PL) indicated that WJ-MSCs are the strongest inhibitors of $\mathrm{T}$ cell proliferation with less immunogenic effects compared with AD-MSCs, BM-MSCs, and PL-MSCs. Nevertheless, hWJ-MSCs had the lowest potential in osteogenesis than that of the PL-MSCs, AD-MSCs and BM-MSCs [159]. Due to the similar features to BM-MSCs including phenotypic characteristics, growth properties, differentiation capacities, secretory protein profiles, and low immunogenicity, perinatal derived MSCs are known as appropriate alternative sources for bone defect repair in patients with osteoporosis [160]. Overall, much more work seems to be needed to identify the appropriate stem cell source for clinical applications in osteoporosis.

\section{Osteogenesis imperfecta (OI)}

Osteogenesis imperfecta (OI) is a heterogeneous prenatal genetic disorder due to mutations in procollagen type I genes (COL1A1/A2) encoding the alpha1 and alpha2 chains of collagen type I which deteriorate the synthesis of this protein by osteoblasts. OI is characterized by progressive skeletal deformation, loss of BMD, frequent fractures, short stature, joint hypermobility, and pain $[8,9]$. There is no definitive cure for OI at present, 
and current therapies are most effective in reducing disease severity. A favorable therapeutic method should replace dysfunctional cells with normal osteoblasts along with prohibition of osteoclast activity for the healthy bone formation [9]. Recently, the preclinical and clinical studies have indicated the successful intrauterine or multi-local engraftment of human fetal (HF) and adult MSCs in both mouse and human model of OI and successful differentiation of transplanted cells into functional osteoblasts [161-163]. Jones et al. suggested the PL as a practical source of stem cells for the treatment of OI based on their study showing that intraperitoneal (IP) injection of human fetal early chorionic stem cells (e-CSCs) in mice models caused the creation of osteoblasts and production of main proteins such as collagen as well as an increase in bone thickness and bone strength [28]. In a mouse model of OI, intrauterine transplantation of human fetal blood MSCs led to an enhancement of osteogenic genes expression such as osteocalcin, osteoprotegerins (OPG), osterix (OSX), and BMP2. The majority of donor cells have tended to migrate to the damaged area in bone and differentiate into collagen type I $\alpha 2$ producing mature osteoblasts [164]. Le Blanc et al. used allogeneic male human fetal mesenchymal stem cells (hf-MSCs) to treat severe OI through intrauterine (IA) MSCs transplantation in female fetus in the 32nd week of gestation. Based on the results, engrafted hf-MSCs were able to differentiate into bone in a human fetus [163]. Transplantation of allogeneic BM-MSCs to children with OI demonstrated retention in one or more sites, including bone, skin, and marrow stroma, and acceleration of growth velocity during the first 6 months after transplantation [162]. Recent research showed that the clinical application of fetal MSCs is constrained due to their limited number and low availability. In contrast, e-CSCs are isolated in high numbers from the placenta during ongoing pregnancy without ethical restrictions [28]. Therefore, adult stem cells are safe for using in clinical trials without inherent limitations pertinent to embryonic stem cells.

\section{Bone fractures}

A bone fracture or an osteotomy is one of the most common injuries among all people particularly elders and children. Every fracture in each site causes individual physical disability, low social efficiency, and imposing financial pressure $[165,166]$. Bone fracture occurs under the circumstances of continuous mechanical stress, trauma, and some diseases such as osteoporosis and cancer [74]. Healing of this type of injury is a complex regenerative process with the involvement of numerous cell types including progenitor, inflammatory, endothelial, and hematopoietic cells as well as growth factors such as TGF- $\beta$ [166, 167]. An effective treatment method for bone repair requires three biological properties: osteoinduction, osteoconduction, and osteointegration [168]. There are numerous therapeutic strategies such as natural bone grafts, using synthetic inorganic substitutes like calcium sulfate, calcium phosphate cements (CPCs), $\beta$-tri-calcium phosphate ( $\beta$-TCP), and polymer-based bone substitutes (e.g., polylactic acid (PLA), poly( $\varepsilon$-caprolactone) (PCL)) for bone fracture repair. These methods are associated with some limitations like invasive surgical procedures, pain, and subsequent complications [169-172]. Researchers investigated new therapeutic approaches for overcoming these challenges and providing higher osteoconductivity. They suggested cell therapy as the best alternative for healing of fractured bone. In this regard, MSCs are one of the most available stem cell sources in bone repair [173, 174]. Generally, safety and efficacy of MSCs from different tissue sources including adipose tissue [30, 175], BM [176, 177], UCB [178], DP [31], and periosteum [179] for fracture regeneration were investigated in animal models. These studies reinforced the beneficial contribution of MSCs from different sources in the bone fracture repair either by differentiation into osteoblasts or through inhibition of inflammatory mediators. Acceleration of bone repair has initially been observed after IV injection of BM stem cells in a mouse model [180]. It is indicated that the controlled delivery of MSCs through biodegradable scaffolds can increase and accelerate the formation of functional new bone [181]. The scaffolds are 3D structures that promote cell adhesion, survival, migration and proliferation, accelerate bone remodeling, provide osteoconductive structural guidance, and in some cases act as the carrier [182]. Marcacci and coworkers were the first to report promising results using autologous in vitro expanded MSCs seeded onto a porous ceramic scaffold of hydroxyapatite (HA), which perfectly fitted the bone injured areas of four patients suffering from large bone diaphysis defects [183].

In addition, several clinical trials at different phases (I, II, or III) have been registered for bone fracture repair using BM-MSCs, AD-MSCs, hUC-MSCs, and human amniotic epithelial cells (ClinicalTrials.gov) which were implanted either via direct injection or after seeding them onto an osteogenic matrix. The required number of cells needed for fracture repair depends on the specific fracture characteristics, cell source, stimulation method, differentiation state, and using biomaterials. A comparison between three main sources of stem cells used to repair bone fractures suggested that isolation efficiency was higher from adipose tissue compared to other sources with respect to cell yield and feasibility. Although the ability for osteogenic differentiation seems to be higher in periosteum-derived mesenchymal stem cells (PD-MSCs), the most widely used cell source is yet 
allocated to $\mathrm{BM}$ for bone fracture repair strategies in recent clinical trials [166].

\section{Cartilage disorders and cell therapy}

Cartilage as a strong supportive connective tissue is found in many areas of the human body including ribs, nose, ear, trachea, and IVD and is an important component of the joints [184-186]. It has dense and highly organized ECM embedding chondrocytes. Collagen type II is the main structural protein in cartilage and forms a meshwork for entrapping proteoglycans such as aggrecan, decorin, and sendycan [187, 188]. Aggrecan and other proteoglycans cause this framework to bound to the water and provide cartilage with tensile strength and flexible construct through which it can act as a supportive structure, maintain the shape, or absorb shock during physical exercise [189]. Three types of cartilages are hyaline (articular), elastic, and fibrocartilage that possess an avascular structure leading to a hypoxic environment with little capacity for self-repair, especially in the case of severe damage due to trauma or age-related degeneration [138, 142]. Hyaline cartilage is the most abundant type present on the articular surfaces of synovial joints providing a smooth, lubricated surface for articulation and facilitating the transmission of loads with a low frictional coefficient $[136,139]$. Chondrocytes are spherical cells in a lacuna within matrix that produce and maintain cartilage architecture and remodel biochemical composition in response to changes in their chemical and mechanical environment in order to regulate cartilage homeostasis [140]. With age, chondrocytes naturally undergo senescent phenotypes and their responsiveness to growth factors reduces which results in accelerating cartilage disruption, cartilage matrix damage, and corresponding diseases [190]. Also, trauma, some diseases, and continual mechanical loading are other important factors for cartilage damage [142]. Due to the limited self-healing capacity of human cartilage, the repair of cartilage defects gives rise to a challenging clinical problem and cartilage regeneration has always been a key therapeutic target for treating articular cartilage damage in particular [139]. In the following sections, common approaches and new therapeutic strategies will be discussed in restoring and treating cartilage defects.

\section{Osteoarthritis (OA)}

Osteoarthritis (OA) is one of the most common arthritis-related chronic disorders characterized by articular cartilage degeneration, thickening of subchondral bone, and osteophyte formation [191-193]. Disability of chondrocytes to produce sufficient functional matrix in order to repair damaged matrix is one of the prominent features of osteoarthritis [194]. OA can be established by activation of matrix proteases which affect joints in the knees and elbow, leading to joint pain, stiffness, swelling, and limitation of joint function [11, 189]. Studies have shown that aging, female gender, obesity, and osteoporosis are significant risk factors associated with OA [195].

Because of the limitation of self-healing capacity of articular cartilage, $\mathrm{OA}$ is one of the most challenging joint diseases. Most conventional treatments for OA such as physical therapy, drug therapy, and surgery are essential to manage the pain, stiffness, and swelling but are not effective to prevent the OA progression [196, 197]. Modern advances in regenerative medicine offer novel methods to treat OA. In recent years, cell therapy, especially with stem cells, is applied for the regeneration of OA damages [198]. By virtue of high proliferative capacity, chondrogenic differentiation capability, and immunosuppressive activities of stem cells, MSC-based therapies have demonstrated acceptable efficacy in cartilage repair in animal and clinical studies [199]. MSCs from various tissues such as adipose tissue [200], BM [201], synovial membrane [202], hUCB [203], and WJ [204] have been considered in different animal models. Overall, the results of investigations demonstrated that MSC-based therapy encourages pain reduction and OA improvement [194] mostly due to the differentiation capability of MSCs. It is demonstrated that both TGF- $\beta 1$ and insulin-like growth factor 1 (IGF-1) act synergistically to stimulate MSCs' chondrogenic differentiation [205].

$\mathrm{BM}$ and adipose tissue are common sources of multipotent cells for regenerating and repairing of an injured tissue. In order to evaluate the repair potential of BMMSCs in OA, researchers showed that intra-articular (IA) injection of BM-MSCs in focal cartilage defects in immunocompetent transgenic rat can lead to collagen and matrix formation [206]. A phase I/II trial indicated that BM-MSCs injection in patients with knee osteoarthritis was associated with cartilage biomarker expression, reducing synovial inflammation, pain, and symptom mitigation, along with no serious adverse events [207]. Also, BM-MSCs exposed to bioactive factors loaded into a sponge composed of a hyaluronan derivative showed chondrogenic differentiation [208]. On the other hand, AD-MSC transplantation in the knee increased the synthesis of glycosaminoglycan, endogenous chondrogenesis supplemented by inflammation reduction, improvement in pain, function, and cartilage volume [209, 210]. MSCs from WJ and hUCB compared to AD-MSCs and BMMSCs have many advantages such as higher proliferation rates, greater expansion ability, higher purity, abundant supply, and inexhaustibility for therapy [211-213]. ECM components in WJ are very similar to those of cartilage ECM. hWJ-MSCs express aggrecan, type II collagen, and SOX-9 as chondrocytes do [213]. Also, hWJ-MSCs express cell growth factors, chemokines, and cytokines 
at similar levels to those of cartilage. These results suggest hWJ-MSCs as appropriate cell candidates for OA's cell therapy [214]. Moreover, the results of xenotransplantation studies showed that human umbilical cord blood-derived mesenchymal stem cells (hUCB-MSCs) are less immunogenic and have higher chondrogenic differentiation potential, therefore promoting cartilage repair without bone formation for a long time [81, 84, 203, 215].

\section{Rheumatoid arthritis (RA)}

Rheumatoid arthritis (RA) is one of the autoimmune inflammatory diseases of the joints presented with an imbalance of both the innate and adaptive immune systems. This disease leads to cartilage and bone degradations, causing pain and stiffness and may occur in other sites including tendon sheaths and bursae. The prevalence of this disease is approximately $0.5-1 \%$ in adults aged $40-50$ years and is more common among women than men [216, 217]. Recently, MSC-based therapies have been suggested as favorable therapeutic approaches for inflammatory cartilage injuries such as RA. MSCs participate in cartilage regeneration after implantation into the injury site and differentiate into chondrocytes [218]. Moreover, MSC therapy reduces pathogenic $T$ cell subsets such as Th1/Th17 cells in the collagen-induced arthritis (CIA) model [219, 220]. Studies showed that MSCs play an important role in inducing apoptosis of activated $\mathrm{T}$ cells via the Fas ligand (FasL)/Fas signaling pathway in arthritis disease [221]. Also, these cells promote immune modulation in RA by suppressing the expression of pro-inflammatory cytokines such as interferon gamma (IFN- $\gamma$ ), TNF- $\alpha$, and matrix-degrading enzymes such as collagenase and gelatinase [222]. Evaluation of BM-MSC therapy on the healing of joints in animals with induced RA demonstrated that inflammation, joint swelling, and destruction of cartilage reduced significantly compared with an arthritic non-treated group [223]. Park and coworkers in the first human trial of hUCBMSCs in patients with RA observed no major toxicity, serious adverse event, or major abnormalities in serum chemicals or hematologic profiles, both during and after the treatment [224]. Allogenic UC-MSCs transplantation in mice model of RA prevented arthritis progression by suppressing $\mathrm{T}$ follicular helper (Tfh) cells proliferation [220].

The investigations showed increased osteoclastic bone resorption as an important factor in the pathogenesis of RA [225]. An experimental study indicated that human gingival tissue-derived MSCs (G-MSCs) inhibit osteoclastogenesis in vitro and in vivo partially via CD39CD73-adenosine signals and have therapeutic effects on bone erosion during CIA in vivo [226]. IV injection of hAD-MSCs in mice with RA reduced the level of pro- inflammatory cytokines while increased the level of antiinflammatory cytokines with an induction in the number and function of regulatory $\mathrm{T}$ cells (Tregs) both in the peripheral blood and in the spleen [227]. Recently, a meta-analysis study compared the effects of MSCs derived from different tissue sources showing that hUCMSCs, hAD-MSCs, and G-MSCs have better treatment effects on RA compared with stem cells from other origins, such as BM [228].

\section{Regeneration mechanisms of mesenchymal stem cells in defected bone and cartilage}

Several in vitro and in vivo studies indicated that MSCs, as the most commonly used stem cells in regenerative medicine, involve in the bone healing process because of their potential to increase osteoinduction and osteogenesis $[229,230]$. These cells can play crucial roles in bone repair and regeneration by several mechanisms (Fig. 2) including facilitating cell migration, homing, angiogenesis, response to inflammation, and differentiation [231].

MSCs have the migration and homing ability into injured sites that are considered as the primary steps for bone formation and defect repair in MSC-based therapy. The recruitment of MSCs is initiated by the response of MSCs to inflammatory factors released from the bone fracture site. These processes are affected by intracellular signaling and interaction between chemokines, chemokine receptors, adhesion molecules, and proteases [232, 233]. Platelet-derived growth factors (PDGFs) and bone morphogenetic proteins (BMPs) play critical roles in bone development and bone fracture healing [234]. PDGF-AA is able to activate BMP-Smad1/5/8 signaling through downregulating platelet-derived growth factor receptor-alpha (PDGFR $\alpha$ ) and promotes MSC migration via BMP-Smad1/5/8-Twist1/Atf4 [235]. Due to vascular damage and hypoxic condition in the injured site, expression of some growth factors such as hypoxiainducible factor $1-\alpha$ (HIF- $1 \alpha)$ increases the production of the stromal cell-derived factor-1 (SDF-1) in the cells of damaged bone. Also, it mediates the expression of its receptor CXC chemokine receptor 4 (CXCR4) in MSCs [236-239]. Therefore, SDF-1/CXCR4 axis promotes the mobilization of MSCs to the defect site and enhances bone regeneration [240]. Expression of CXCR4 and Cbfa1 (core binding factor alpha 1, also called Runx2) increased MSC homing and promoted bone formation after four weeks of transplantation [158]. In vitro and in vivo studies showed that TNF- $\alpha$, as one of the main proinflammatory cytokines, induces the expression of LRG1 through p38 and nuclear factor kappa-B $(\mathrm{NF}-\mathrm{kB})$ signaling to promote angiogenesis and MSC migration [241].

Transplanted MSCs can contribute to bone regeneration through angiogenesis stimulation [242]. hMSCs 


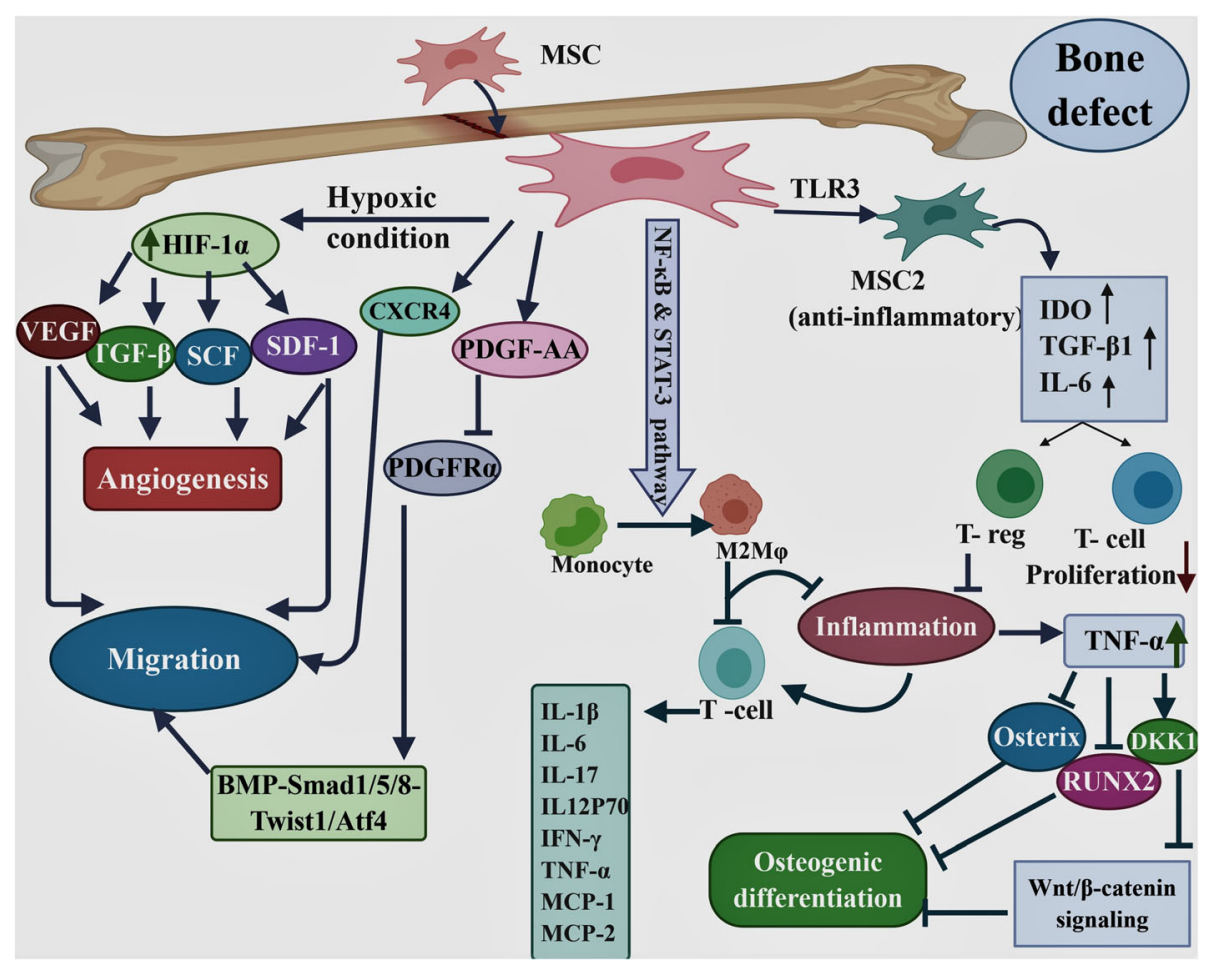

Fig. 2 Schematic summarizing the mechanisms of repairing bone by MSCs. The figure was designed using the web-based tool BioRender. Mesenchymal stem cells (MSCs) contribute to bone regeneration by several mechanisms including migration, angiogenesis, response to inflammation condition, and differentiation through production of a variety of mediators. Hypoxia-inducible factor 1-a (HIF-1a), stem cell factor (SCF), transforming growth factor-beta (TGF- $\beta$ ), vascular endothelial growth factor(VEGF), stromal cell-derived factor (SDF)-1, and CXC chemokine receptor (CXCR) 4, platelet-derived growth factor (PDGF-AA), platelet-derived growth factor receptor-alpha (PDGFRa), Toll-like receptors (TLRs), nitric oxide (NO), indoleamine 2,3-dioxygenase (IDO), regulatory T cell (T reg), nuclear factor kappa-B (NF-kB), signal transducer and activator of transcription 3 (STAT-3), interferon gamma (IFN- $\gamma$ ), tumor necrosis factor alpha (TNF-a), monocyte chemoattractant proteins-1 (MCP-1), macrophage inflammatory protein-1(MIP-1), Dickkopf 1(DKK1), runt-related transcription factor 2 (RUNX2), M2 type of macrophage (M2MQ)

reside in hypoxic perivascular niches [243], express HIF$1 \alpha$ in response to hypoxic condition in defect site [244247], and induce the expression of angiogenic factors such as VEGF, TGF- $\beta$, SDF-1, and stem cell factor (SCF) [248]. The studies showed that VEGF plays an important role in neovascularization and angiogenesis during the development of most tissues including bone [249, 250].

Inflammation in damaged tissue stimulates macrophages and $\mathrm{T}$ lymphocytes for necrotic tissue phagocytosis and also induces inflammatory cytokines such as IL-1, IL-6, TNF- $\alpha$, IFN- $\gamma$, monocyte chemoattractant proteins-1 (MCP-1), macrophage inflammatory protein-1 (MIP-1), and IL-17 [251, 252]. Although the inflammatory responses contribute substantially to bone regeneration, prolonged inflammation is harmful and retards the bone healing process [181]. BM, adipose tissue, CB, and WJ-derived MSCs cause reduction in IFN- $\gamma$ and/or TNF- $\alpha$ secretion from T cells and suppress $\mathrm{T}$ cell proliferation [253]. In addition, MSCs significantly suppress the production of the inflammatory cytokines IL-6, IL-12p70, and IFN- $\gamma$ while increase the production of anti-inflammatory cytokines IL-10 and IL-12p40
[254]. In response to inflammation and high levels of pro-inflammatory factors such as IFN- $\gamma$, TNF- $\alpha$, and IL$1 \beta$, MSCs are stimulated to start producing antiinflammatory factors such as nitric oxide (NO), indoleamine 2,3-dioxygenase (IDO), and anti-inflammatory cytokines and chemokines, which is followed by immunosuppression [255]. Three days after bone fracture, transplanted MSCs are capable of limiting tissue injury by significant reduction in IL- 6 , TNF- $\alpha$, and IL- $1 \beta$ levels and preventing the progression of fibrosis and thus improve bone regeneration [256].

Another immunomodulatory mechanism of MSCs is inducing the polarization of monocytes into antiinflammatory M2 macrophages through signal transducer and activator of transcription 3 (STAT-3), and NF- $\mathrm{KB}$ leading to indirectly suppression of $\mathrm{T}$ cell proliferation [257-259].

Toll-like receptors (TLRs) are highly expressed on MSCs and have profound effects on proliferation, migration, immunomodulatory functions, and survival of MSCs [229, 231, 260, 261]. TLR4 polarizes MSCs toward a pro-inflammatory phenotype (MSC1) which has 
critical role in early injury responses and lead to collagen deposition, expression of pro-inflammatory mediators, and reversal of the $\mathrm{T}$ cell suppressive mechanism [262]. In contrast, TLR3 supports the immune suppression and anti-inflammatory phenotype in MSCs, named MSC2 [263], which can suppress the T lymphocyte proliferation and induce regulatory $\mathrm{T}$ cell (Treg) generation by secreting soluble factors such as IDO, TGF- $\beta 1$, and IL-6 [264]. In hAD-MSCs, activation of TLR2, TLR3, TLR4, and TLR9 leads to manganese superoxide dismutase (MnSOD) expression with an eminent impact on engraftment and survival of AD-MSCs in inflammatory conditions or injured tissues [265].

The most common therapeutic effects of MSCs are their incorporation into the host tissue and osteogenesis differentiation ability which are influenced by numerous cytokines and growth factors such as TGF $\beta-1$ and WNT [266, 267]. Also, matrix metalloproteinases (MMPs) have critical role in the differentiation of MSCs to adipocytes, osteocytes, and chondrocytes. The MMP-1, MMP-13 (collagenase), and MMP-3 (Stromelysin-1) cleave ECM proteins [268]. The lowest production of MMP-1 and MMP-3 and no secretion of MMP-13 by BM-MSCs make them as suitable candidates for bone, cartilage, and tendon regeneration [269].

TNF- $\alpha$, as a pro-inflammatory cytokine, is highly expressed in inflammatory sites of bone and causes tumor necrosis factor receptor1 (TNFR1) activation $[270,271]$ and receptor activator of nuclear factor kappa-B ligand (RANKL) upregulation in osteoblasts [271]. Subsequently, NF- $\mathrm{kB}$ pathway is activated by receptor activator of nuclear factor kappa-B (RANK)/ RANKL signaling [272] which activates apoptotic factors including p21 and p53 [273, 274] and, as a result, inhibits MSC differentiation and increases apoptosis of osteoblasts and their progenitors [273]. Another important effect of TNF- $\alpha$ in inflammatory conditions is inhibition of two essential osteogenic differentiation factors including RUNX2 and osterix, leading to the suppression of MSC differentiation [275, 276]. It has been indicated that commitment of MSCs into the osteoblast lineage is regulated by $\mathrm{Wnt} / \beta$-catenin signaling pathway [277]. $\beta$ catenin serves a notable role in the progression of MSC precursors differentiation into mature osteoblasts by upregulating the osteogenic regulators Runx2, Dlx5, and Osterix [278-280]. During inflammation, TNF- $\alpha$ suppresses $\mathrm{Wnt} / \beta$-catenin signaling by inducing Wntsignaling inhibitor, Dickkopf 1 (DKK1), and finally inhibits bone formation [281]. TNF- $\alpha$ which is released by activated immune cells such as $\mathrm{T}$ cells interacts with the TNF receptors on MSCs and leads to the production of prostaglandin E2 (PGE2), which then is the underlying reason of the suppression of $\mathrm{T}$ lymphocyte proliferation and consequently prevention of TNF- $\alpha$ expression [282,
283]. Also, IL-1RA released by MSCs induces IL-10 in stimulated DCs and inhibits TNF- $\alpha$ production by activated macrophages which results in accelerating bone healing [245].

Also, MSCs can express BMP-2 in defect site, which induces the differentiation of these cells into osteoblasts in an autocrine manner [177, 284]. BMP-2 plays an important role in bone healing due to the involvement in new bone tissue formation, increasing osteoblast function and the maintenance of the dynamic balance of the newly formed bone tissue $[285,286]$. Through interacting with expressed BMP receptors, BMPs trigger two signal pathways including Smad-dependent pathways and the mitogen-activated protein kinase (MAPK) pathway, thereby involving in osteogenesis [287, 288].

The extracellular vesicles (EVs) produced by MSCs have been indicated as a novel therapeutic method for bone diseases such as osteoporosis. Exosomes are one of the most important EVs released by MSCs that can be directly used as therapeutic agents for various bone diseases [289]. The investigations indicated that exosomes secreted by MSCs promote osteoblast proliferation, differentiation, and bone formation, which improve bone regeneration in osteoporotic rats [290]. Through increasing the osteogenesis and angiogenesis-related genes expression, such as COL I, alkaline phosphatase (ALP), and VEGF, MSC-derived exosomes can promote bone formation [291]. In addition, exosomes contribute to bone repair and accelerate fracture healing through their cytokine content such as MCP-1, MCP-3, and SDF-1 [292].

Numerous studies have demonstrated the successful MSC transplantation for healing of chondral lesions and repairing the damaged cartilage (Fig. 3). There are two main concepts for MSCs contribution to cartilage disease improvement: first, preventing the degradation of cartilage through the secretion of bioactive factors, and second, differentiating potential of MSCs to become chondrocytes [293, 294]. Pro-inflammatory cytokines including TNF- $\alpha$, IL- 6 , IL-1 $\beta$, and IL-17 play important roles in the development of pathological conditions in cartilage diseases [295]. MSCs modulate host immune responses by inhibiting the proliferation of $\mathrm{T}$ lymphocytes and pro-inflammatory cytokine secretion by prostaglandin E2 (PGE2) [296, 297].

MMP-2, MMP-9, and MMP-13 were detected at higher levels in human OA cartilage [298]. MSCs secrete high levels of tissue inhibitor of metalloproteinases 2 (TIMP2) and TIMP-1 inhibitors, which inhibit MMP-2 and MMP-9, respectively, and suppress cartilage ECM destruction [298]. MSCs secret hepatocyte growth factor (HGF) through which inhibit the fibrosis and apoptosis of chondrocytes, but stimulate the proliferation of these cells, and increase ECM synthesis [299]. The EVs 


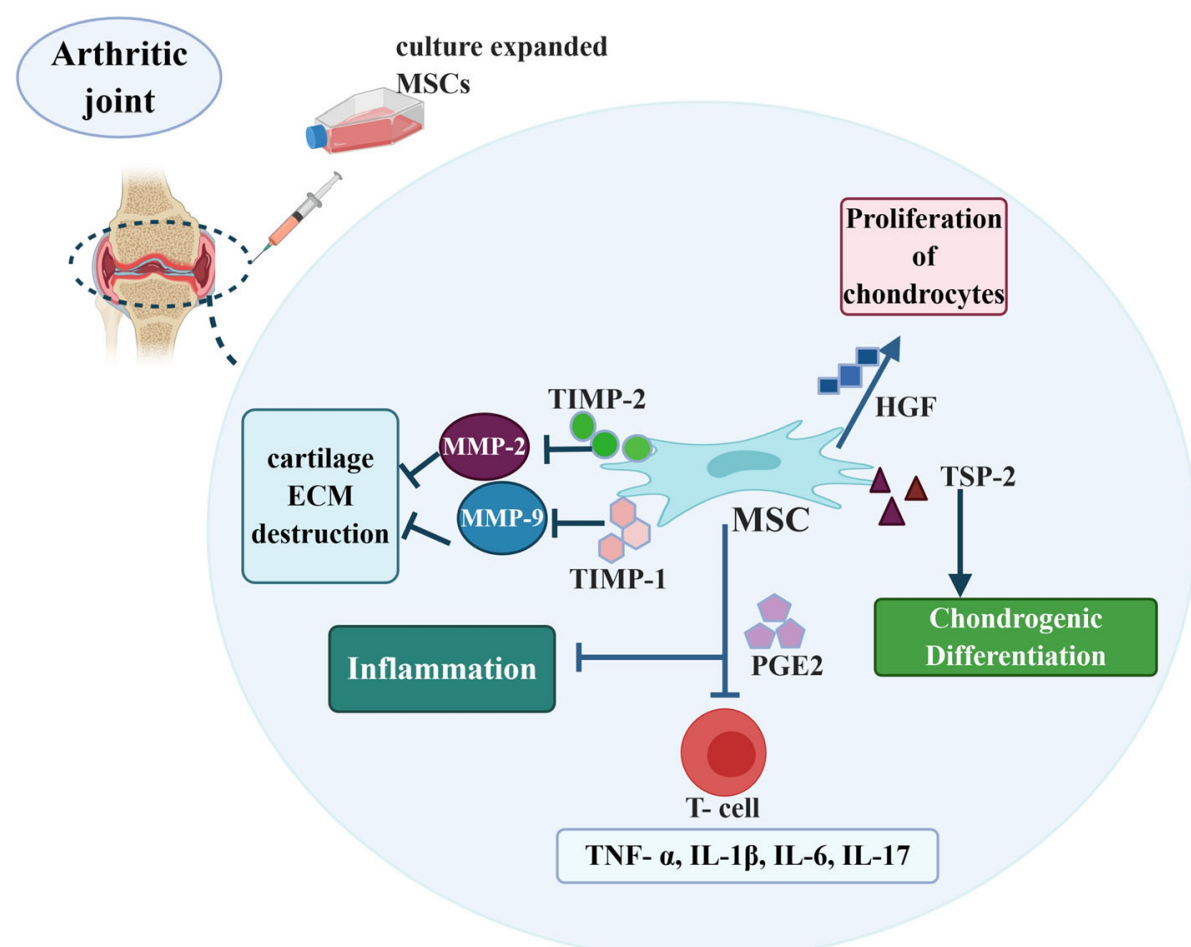

Fig. 3 Mechanisms of MSC-mediated cartilage repair. The figure was designed using the web-based tool BioRender. Mesenchymal stem cells (MSCs) contribute to cartilage regeneration by several mechanisms including response to inflammation condition and differentiation through production of a variety of mediators. Matrix metalloproteinase (MMP), tissue inhibitors of metalloproteinases (TIMP), tumor necrosis factor alpha (TNF-a), prostaglandin E2 (PGE2), interleukin (IL), hepatocyte growth factor (HGF), thrombospondin (TSP2)

produced by MSCs can reduce arthritis scores and pathological changes in inflamed cartilage by decreasing plasma blast population and increasing IL-10 secretion of regulatory B cells [300]. MSC's exosomes can cause an early suppression of local inflammation in OA through a significantly reduced expression of inflammatory genes especially IL-1 $\beta$ [301, 302]. In vitro studies demonstrated that exosomes derived from BM-MSCs are able to stimulate the expression of chondrocyte markers such as type II collagen and aggrecan while inhibit MMP-13 and ADAMTS5 as catabolic markers in OA-like chondrocytes [303].

Different growth factors, cytokines, and signaling molecules including TGF- $\beta$ superfamily regulate chondrogenic induction and differentiation of MSCs. TGF- $\beta 2$, TGF- $\beta 1$, and TGF- $\beta 3$ stimulate the synthesis of collagen type II and proteoglycans and contribute to the MSC differentiation to chondrocytes [304, 305]. TGF- $\beta$ signaling mediates chondrogenesis by activating and phosphorylating Smad2/3. Phosphorylated Smad translocates into the nucleus and binds to the master chondrogenic transcription factors such as SOX9 and collagen type II (COL II) which are expressed in all chondrocyte progenitors and chondrocytes [306, 307]. Other factors that influence MSC differentiation and chondrogenesis are Wnt $/ \beta$-catenin signaling pathway family and MAP kinases $[308,309]$. Thrombospondin (TSP2), as a regulator of cartilage and bone differentiation, is secreted by MSCs and promotes chondrogenic differentiation of progenitor cells by protein kinase $\mathrm{C}$ alpha (PKC $\mathrm{P})$, extracellular signal-regulated kinase (ERK), p38/MAPK, and Notch signaling pathways [310, 311]. Moreover, some trophic factors such as VEGF, epidermal growth factor (EGF), and an array of bioactive molecules also affect chondrogenic differentiation from MSCs and cartilage matrix formation [312].

\section{Selection of appropriate source of stem cell based on their protein expression profile}

MSC therapy has been used for repairing both the structure and function of injured bone and cartilage tissues $[158,313]$. In addition to differentiation capacity to the different cell types, MSCs obtained from various sources have diverse capabilities of secreting many different cytokines, growth factors, and chemokines and thus differentially influence angiogenesis, inflammation, apoptosis, stem cell homing, stem cell survival, proliferation potential, and migration to the damaged areas [314-317].

Amable et al. showed that WJ-MSCs have a higher proliferation potential, higher production of pro- 
inflammatory cytokines such as IL-6, and higher expression of some growth factors such as PDGF, HGF, and TGF- $\beta$ compared with AD-MSCs and BM-MSCs. WJMSCs also produce a higher concentration of some proangiogenic proteins such as VEGF, ECM components such as collagen, and MMPs such as MMP1 and MMP3 in AD-MSC supernatants. In contrast, BM-MSCs secrete the lowest amount of all chemokines in comparison with stem cells from other sources [269]. Comparison of cytokine expression profile including macrophage migration inhibitory factor (MIF), IL-8, Serpin E1, growthregulated oncogene $\alpha$ (GRO $\alpha)$ and IL-6 in MSCs from human PL (amnion, decidua), cord blood (CB), and BM by Hwang et al. represented similar expression pattern in all three cell types. However, BM-MSCs express higher MCP-1 and are the only MSC type that produces SDF-1, but the expression of IL- 6 by the CB-MSCs was comparatively lower [318].

hAD-MSCs, BM-MSCs, and UCB-MSCs express high levels of TLRs [319-321] compared with WJ-MSCs $[228,322]$. One of the studies reported that human olfactory ecto MSCs (OE-MSCs) express high levels of TLR3 and TLR4 genes, as well as higher levels of cytokines and chemokines including CCL5, IL-8, and TGF- $\beta$ in comparison with AD-MSCs [323]. In another study, perivascular stem cells derived from umbilical arteries (UCA-PSCs) and PSCs derived from umbilical vein (UCV-PSCs) showed higher expression of angiogenesisrelated genes, such as CXCL12(SDF-1), HIF-1 $\alpha$, and ERAP1 in comparison with WJ-MSCs. In addition, higher expression of angiogenesis related genes such as CD146 and Jagged1 was detected in UCA-PSCs. Consequently, UCA-PSCs and UCV-PSCs, especially UCAPSCs, demonstrated better angiogenic capability than WJ-MSCs [260].

Based on these investigations, identification of MSCs in terms of proteins expression and secretory factors has been of great benefit to appropriate cell source selection for each disease.

\section{Conclusion}

Osteochondral complications promise as significant cause of disability and pain. Although the degenerative conditions are progressive, there has been no definitive therapy and almost all currently therapies try to control the symptoms. MSC-based therapy is introduced as a promising treatment strategy with potential ameliorating effects on disease progression. Despite using various sources of MSCs for bone defect therapy, BM-MSCs and AD-MSCs are widely applicable in human trials. Comparison of main sources of cellular tissue revealed that $\mathrm{BM}$ remains the most widely used source for bone fracture repair strategies as 14 of the 17 registered clinical trials have used BM-MSCs. However, both adipose tissue and bone marrow seem to be promising stem cell sources for osteoarthritis therapy. In addition, WJ-MSCs possess similar ECM components with cartilage and express cell growth factors, chemokines, and cytokines at levels similar to those of cartilage. Thus, they are appropriate cell candidates for osteoarthritis cell therapy. HUCB-MSCs are less immunogenic and have the chondrogenic differentiation potential, therefore promoting cartilage repair without bone formation in a long period of time. All in all, clinical trials have confirmed a relative safety of using MSCs in the treatment of osteochondral defects with both reparative and preventative effects rather than generally accepted pain managements. However, culturing and expanding these cells should be carried out with further caution and in controlled ex vivo preparation conditions.

\section{Abbreviations}

MSCs: Mesenchymal stem cells; BM: Bone marrow; UC: Umbilical cord; UCB: Umbilical cord blood; PL: Placenta; WJ: Wharton's jelly;

IVDs: Intervertebral discs; Ol: Osteogenesis imperfecta; OA: Osteoarthritis; RA: Rheumatoid arthritis; HA: Hyaluronic acid; GAGs: Glycosaminoglycans; DP: Dental pulp; hMSCs: Human MSCs; VEGF: Vascular endothelial growth factor; TGF- $\beta$ : Transforming growth factor beta; ILs: Interleukins; DC: Dendritic cell; ECM: Extracellular matrix; BM-MSCs: Bone marrow-derived mesenchymal stem cells; NP: Nucleus pulposus; AF: Anulus fibrosus; CEPs: Cartilaginous end plates; MMPs: Matrix metalloproteinases; DDD: Degenerative disc disease;

TNF-a: Tumor necrosis factor alpha; AD-MSCs: Adipose-derived mesenchymal stem cells; MdSCs: Muscle-derived stem cells; BMD: Bone mineral density; HF: Human fetal; IA: Intra-articular; IP: Intraperitoneal; IV: Intravenous; eCSCs: Human fetal early chorionic stem cells; OPG: Osteoprotegerins; OSX: Osterix; BMP: Bone morphogenetic protein; CPCs: Calcium phosphate cements; $\beta$-TCP: $\beta$-tri-calcium phosphate; PLA: Polylactic acid; PCL: Poly( $\varepsilon$ caprolactone); IGF-1: Insulin-like growth factor 1; CIA: Collagen-induced arthritis; IFN-Y: Interferon gamma; Tfh: T follicular helper; G-MSCs: Gingival tissue-derived MSCs; Tregs: Regulatory T cells; PDGFs: Platelet-derived growth factors; PDGFRa: Platelet-derived growth factor receptor-alpha; HIF-

1a: Hypoxia-inducible factor 1-a; SDF-1: Stromal cell-derived factor-1; CXCR4: CXC chemokine receptor 4; PD-MSCs: Periosteum-derived mesenchymal stem cells; NF-KB: Nuclear factor kappa-B; SCF: Stem cell factor; MIP-1: Macrophage inflammatory protein-1; NO: Nitric oxide;

IDO: Indoleamine 2,3-dioxygenase; STAT-3: Signal transducer and activator of transcription 3; MnSOD: Manganese superoxide dismutase; TNFR1: Tumor necrosis factor receptor1; PGE2: Prostaglandin E2; IL-1RA: Interleukin-1 receptor antagonist; MAPK: Mitogen activated protein kinase; TIMP-2: Tissue inhibitor of metalloproteinases-2; EGF: Epidermal growth factor;

HGF: Hepatocyte growth factor; MIF: Macrophage migration inhibitory factor; GROa: Growth-regulated oncogene a; CB: Cord blood; MCP-1: Monocyte chemoattractant protein-1; TLRs: Toll-like receptors; OE-MSCs: Olfactory ecto MSCs; UCA-PSCs: Perivascular stem cells derived from umbilical arteries; UCVPSCs: Perivascular stem cells derived from umbilical vein

\section{Acknowledgements}

Not applicable.

\section{Authors' contributions}

PK prepared the first draft, TTKH edited the second draft and suggested to add some parts, IRJ edited the second draft, and MR coordinated the whole project including the preparation of the outlines, edition of the first draft, and final proofreading. The authors read and approved the final manuscript.

\section{Funding}

This work was financially supported by Shiraz University of Medical Sciences, Shiraz, Iran (Grant No. 99-01-16-22192) and Shiraz Institute for Cancer Research (ICR100-504). 


\section{Availability of data and materials}

Not applicable.

\section{Ethics approval and consent to participate}

Not applicable.

\section{Consent for publication}

Not applicable.

\section{Competing interests}

The authors declare that they have no competing interests.

\section{Author details}

'Department of Tissue Engineering and Applied Cell Sciences, School of Advanced Technologies in Medicine, Shiraz University of Medical Sciences, Shiraz, Iran. ${ }^{2}$ Tissue Engineering Laboratory, Department of Anatomy, School of Medicine, Shiraz University of Medical Sciences, Shiraz, Iran.

${ }^{3}$ Cardiovascular Research Center, Shiraz University of Medical Sciences, Shiraz, Iran. ${ }^{4}$ Shiraz Institute for Cancer Research, School of Medicine, Shiraz University of Medical Sciences, Shiraz, Iran.

Received: 29 July 2020 Accepted: 27 October 2020

Published online: 23 November 2020

\section{References}

1. Podgorski I. Future of anticathepsin K drugs: dual therapy for skeletal disease and atherosclerosis? 2009.

2. Goltzman D. Discoveries, drugs and skeletal disorders. Nat Rev Drug Discov. 2002;1(10):784-96

3. Friedman BW, O'Mahony S, Mulvey L, Davitt M, Choi H, Xia S, Esses D, Bijur PE, Gallagher EJ. One-week and 3-month outcomes after an emergency department visit for undifferentiated musculoskeletal low back pain. Annals Emerg Med. 2012:59(2):128-33 e123.

4. Kepler CK, Ponnappan RK, Tannoury CA, Risbud MV, Anderson DG. The molecular basis of intervertebral disc degeneration. Spine J. 2013;13(3): 318-30.

5. Feng $Y$, Egan B, Wang J. Genetic factors in intervertebral disc degeneration. Genes Diseases. 2016;3(3):178-85.

6. Lane NE. Epidemiology, etiology, and diagnosis of osteoporosis. Am J Obstet Gynecol. 2006;194(2):S3-S11.

7. Marini F, Brandi ML. Genetic determinants of osteoporosis: common bases to cardiovascular diseases? Int J Hypertens. 2010;2010.

8. Zhytnik L, Maasalu K, Reimann E, Prans E, Kõks S, Märtson A. Mutational analysis of COL1A1 and COL1A2 genes among Estonian osteogenesis imperfecta patients. Human genomics. 2017;11(1):19.

9. Morello R. Osteogenesis imperfecta and therapeutics. Matrix Biol. 2018;71: 294-312.

10. Marini JC, Cabral WA: Osteogenesis imperfecta. In: Genetics of Bone Biology and Skeletal Disease. edn.: Elsevier; 2018: 397-420.

11. Yucesoy B, Charles LE, Baker B, Burchfiel CM. Occupational and genetic risk factors for osteoarthritis: a review. Work. 2015:50(2):261-73.

12. Van der Kraan P. Osteoarthritis year 2012 in review: biology. Osteoarthr Cartil. 2012:20(12):1447-50

13. Van Meurs J. Osteoarthritis year in review 2016: genetics, genomics and epigenetics. Osteoarthr Cartil. 2017;25(2):181-9.

14. Reynard LN, Barter MJ. Osteoarthritis year in review 2019: genetics, genomics and epigenetics. Osteoarthr Cartil. 2020;28(3):275-84.

15. Hasan M, Shuckett R. Clinical features and pathogenetic mechanisms of osteoarthritis of the hip and knee. BC Med J. 2010:52(8):393-8.

16. Deane KD, Demoruelle MK, Kelmenson LB, Kuhn KA, Norris JM, Holers VM Genetic and environmental risk factors for rheumatoid arthritis. Best Pract Res Clin Rheumatol. 2017:31(1):3-18.

17. Mount NM, Ward SJ, Kefalas P, Hyllner J. Cell-based therapy technology classifications and translational challenges. Phil Trans R Soc B. 2015: 370(1680):20150017

18. Hima Bindu A, Srilatha B. Potency of various types of stem cells and their transplantation. J Stem Cell Res Ther. 2011;1:115.

19. Sheng G. The developmental basis of mesenchymal stem/stromal cells (MSCs). BMC Dev Biol. 2015;15(1):44
20. Xu X, Chen C, Akiyama K, Chai Y, Le A, Wang Z, Shi S. Gingivae contain neural-crest-and mesoderm-derived mesenchymal stem cells. J Dent Res. 2013;92(9):825-32.

21. Saeed H, Ahsan M, Saleem Z, latedar M, Islam M, Danish Z, Khan AM. Mesenchymal stem cells (MSCs) as skeletal therapeutics-an update. J Biomed Sci. 2016;23(1):41.

22. Omlor G, Lorenz S, Nerlich A, Guehring T, Richter W. Disc cell therapy with bone-marrow-derived autologous mesenchymal stromal cells in a large porcine disc degeneration model. Eur Spine J. 2018;27(10):2639-49.

23. Jeong JH, Lee JH, Jin ES, Min JK, Jeon SR, Choi KH. Regeneration of intervertebral discs in a rat disc degeneration model by implanted adiposetissue-derived stromal cells. Acta Neurochir. 2010;152(10):1771-7.

24. Elabd C, Centeno CJ, Schultz JR, Lutz G, Ichim T, Silva FJ. Intra-discal injection of autologous, hypoxic cultured bone marrow-derived mesenchymal stem cells in five patients with chronic lower back pain: a long-term safety and feasibility study. J Transl Med. 2016;14(1):253.

25. Orozco L, Soler R, Morera C, Alberca M, Sánchez A, García-Sancho J. Intervertebral disc repair by autologous mesenchymal bone marrow cells: a pilot study. Transplantation. 2011:92(7):822-8.

26. Cao L, Liu G, Gan Y, Fan Q, Yang F, Zhang X, Tang T, Dai K. The use of autologous enriched bone marrow MSCs to enhance osteoporotic bone defect repair in long-term estrogen deficient goats. Biomaterials. 2012; 33(20):5076-84.

27. Hong B, Lee S, Shin N, Ko Y, Kim D, Lee J, Lee W. Bone regeneration with umbilical cord blood mesenchymal stem cells in femoral defects of ovariectomized rats. Osteoporosis Sarcopenia. 2018:4(3):95-101.

28. Jones GN, Moschidou D, Abdulrazzak H, Kalirai BS, Vanleene M, Osatis S, Shefelbine SJ, Horwood NJ, Marenzana M, De Coppi P. Potential of human fetal chorionic stem cells for the treatment of osteogenesis imperfecta. Stem Cells Dev. 2014:23(3):262-76.

29. Horwitz EM, Prockop DJ, Fitzpatrick LA, Koo WW, Gordon PL, Neel M, Sussman M, Orchard P, Marx JC, Pyeritz RE. Transplantability and therapeutic effects of bone marrow-derived mesenchymal cells in children with osteogenesis imperfecta. Nat Med. 1999:5(3):309-13.

30. Arrigoni E, De Girolamo L, Di Giancamillo A, Stanco D, Dellavia C, Carnelli D, Campagnol M, Domeneghini C, Brini AT. Adipose-derived stem cells and rabbit bone regeneration: histomorphometric, immunohistochemical and mechanical characterization. J Orthop Sci. 2013;18(2):331-9.

31. Kitraki E, Zakkas S, Synolaki E, Diamanti E, Tiniakos DG, Stamatakis A, Matsioula C, Stylianopoulou F, Papapolychroniou T. Dental pulp cells enhance bone healing in a rat osteotomy model. Ann Orthop Rheumatol. 2014;2(1):1009.

32. Thua THL, Bui DP, Nguyen DT, Pham DN, Le QB, Nguyen PH, Tran NV, Le $P Q$, Boeckx WD, De Mey A. Autologous bone marrow stem cells combined with allograft cancellous bone in treatment of nonunion. Biomedical Res Therapy. 2015;2(12):1-9.

33. Kim JE, Lee SM, Kim SH, Tatman P, Gee AO, Kim D-H, Lee KE, Jung Y, Kim SJ Effect of self-assembled peptide-mesenchymal stem cell complex on the progression of osteoarthritis in a rat model. Int J Nanomedicine. 2014 9(Suppl 1):141

34. Davatchi F, Abdollahi BS, Mohyeddin M, Shahram F, Nikbin B. Mesenchymal stem cell therapy for knee osteoarthritis. Preliminary report of four patients. Int J Rheum Dis. 2011:14(2):211-5.

35. Emadedin M, Aghdami N, Taghiyar L, Fazeli R, Moghadasali R, Jahangir S, Farjad R, Eslaminejad MB: Intra-articular injection of autologous mesenchymal stem cells in six patients with knee osteoarthritis. Archives Iranian Med 2012, 15(7):0-0.

36. Jo CH, Lee YG, Shin WH, Kim H, Chai JW, Jeong EC, Kim JE, Shim H, Shin JS, Shin IS. Intra-articular injection of mesenchymal stem cells for the treatment of osteoarthritis of the knee: a proof-of-concept clinical trial. Stem Cells. 2014;32(5):1254-66.

37. Vadalà G, Russo F, Ambrosio L, Loppini M, Denaro V. Stem cells sources for intervertebral disc regeneration. World J Stem Cells. 2016;8(5):185.

38. Vinatier C, Bordenave L, Guicheux J, Amedee J. Stem cells for osteoarticular and vascular tissue engineering. Med Sci. 2011;27(3):289-96.

39. Gao F, Chiu S, Motan D, Zhang Z, Chen L, Ji H, Tse H, Fu Q-L, Lian Q. Mesenchymal stem cells and immunomodulation: current status and future prospects. Cell Death Dis. 2017;7(1):e2062.

40. Sakaida ITS, Yamamoto N, Aoyama K, Ishikawa T, Nishina H, et al. Transplantation of bone marrow cells reduces CCl4-induced liver fibrosis in mice. Hepatology. 2004;40:1304-11. 
41. Tocci AF, L. Mesenchymal stem cell: use and perspectives. Hematol J. 2003; 4(2):92-6.

42. Huang GT, Gronthos S, Shi SJ. Mesenchymal stem cells derived from dental tissues vs. those from other sources: their biology and role in regenerative medicine. Dent Res. 2009;88:792-806.

43. Seifrtova M, Havelek R, Cmielova J, Jiroutova A, Soukup T, Bruckova L, Mokry J, English D, Rezacova M. The response of human ectomesenchymal dental pulp stem cells to cisplatin treatment. Int Endod J. 2012;45:401-12.

44. Morito T, Muneta T, Hara K, Ju YJ, Mochizuki T, Makino H, Umezawa AaS I. Synovial fluid-derived mesenchymal stem cells increase after intra-articular ligament injury in humans. Rheumatology. 2008;47:1137-43.

45. Bartsch G, Yoo JJ, De Coppi P, Siddiqui MM, Schuch G, Pohl HG, Fuhr J, Perin L, Soker S, Atala A. Propagation, expansion, and multilineage differentiation of human somatic stem cells from dermal progenitors. Stem Cells Dev. 2005;14:337-48.

46. Riekstina U, Muceniece R, Cakstina I, Muiznieks I, Ancans J. Characterization of human skin-derived mesenchymal stem cell proliferation rate in different growth conditions. Cytotechnology. 2008;58:153-62.

47. Marino L, Castaldi MA, Rosamilio R, Ragni E, Vitolo R, Fulgione C, Castaldi SG, Serio B, Bianco R, Guida M. Mesenchymal stem cells from the Wharton's jelly of the human umbilical cord: biological properties and therapeutic potential. International journal of stem cells. 2019;12(2):218.

48. de la Torre P, Pérez-Lorenzo MJ, Flores Al: Human placenta-derived mesenchymal stromal cells: a review from basic research to clinical applications. In: Stromal Cells-Structure, Function, and Therapeutic Implications. edn.: IntechOpen; 2018.

49. Bakopoulou A, Georgopoulou A, Grivas I, Bekiari C, Prymak O, Loza K, Epple M, Papadopoulos GC, Koidis P, Chatzinikolaidou M. Dental pulp stem cells in chitosan/gelatin scaffolds for enhanced orofacial bone regeneration. Dent Mater. 2019;35(2):310-27

50. Al-Qadhi G, Soliman M, Abou-Shady I, Rashed L. Gingival mesenchymal stem cells as an alternative source to bone marrow mesenchymal stem cells in regeneration of bone defects: in vivo study. Tissue Cell. 2020;63: 101325.

51. Ghaderi H, Razmkhah M, Kiany F, Chenari N, Haghshenas MR, Ghaderi A. Comparison of osteogenic and chondrogenic differentiation ability of buccal fat pad derived mesenchymal stem cells and gingival derived cells. J Dent. 2018;19(2):124-31.

52. Ayatollahi M, Talaei-Khozani T, Razmkhah M. Growth suppression effect of human mesenchymal stem cells from bone marrow, adipose tissue, and Wharton's jelly of umbilical cord on PBMCs. Iranian J Basic Med Sci. 2016; 19(2):145.

53. Lindenmair A, Hatlapatka T, Kollwig G, Hennerbichler S, Gabriel C, Wolbank $\mathrm{S}$, Redl H, Kasper C. Mesenchymal stem or stromal cells from amnion and umbilical cord tissue and their potential for clinical applications. Cells. 2012; 1(4):1061-88.

54. Chen L, Qu J, Cheng T, Chen X, Xiang C. Menstrual blood-derived stem cells: toward therapeutic mechanisms, novel strategies, and future perspectives in the treatment of diseases. Stem Cell Res Ther. 2019;10(1):406.

55. Dominici M, Le Blanc K, Mueller I, Slaper-Cortenbach I, Marini F, Krause D, Deans R, Keating A, Prockop D, Horwitz E. Minimal criteria for defining multipotent mesenchymal stromal cells. The International Society for Cellular Therapy position statement. Cytotherapy. 2006;8:315-7.

56. Samsonraj RM, Raghunath M, Nurcombe V, Hui JH, van Wijnen AJ, Cool SM. Concise review: multifaceted characterization of human mesenchymal stem cells for use in regenerative medicine. Stem Cells Transl Med. 2017;6(12): 2173-85.

57. Bourin P, Bunnell BA, Casteilla L, Dominici M, Katz AJ, March KL, Redl H, Rubin JP, Yoshimura K, Gimble JM. Stromal cells from the adipose tissue-derived stromal vascular fraction and culture expanded adipose tissue-derived stromal/stem cells: a joint statement of the International Federation for Adipose Therapeutics and Science (IFATS) and the International Society for Cellular Therapy (ISCT). Cytotherapy. 2013;15(6): 641-8.

58. Yoshimura K, Shigeura T, Matsumoto D, Sato T, Takaki Y, Aiba-Kojima E, Sato K, Inoue K, Nagase T, Koshima I. Characterization of freshly isolated and cultured cells derived from the fatty and fluid portions of liposuction aspirates. J Cell Physiol. 2006:208(1):64-76.

59. Fan J, Varshney RR, Ren L, Cai D, Wang D-A. Synovium-derived mesenchymal stem cells: a new cell source for musculoskeletal regeneration. Tissue Eng B Rev. 2009;15(1):75-86.
60. Struys T, Moreels M, Martens W, Donders R, Wolfs E, Lambrichts I. Ultrastructural and immunocytochemical analysis of multilineage differentiated human dental pulp-and umbilical cord-derived mesenchymal stem cells. Cells Tissues Organs. 2011;193(6):366-78.

61. Vishwanath VR, Nadig RR, Nadig R, Prasanna JS, Karthik J, Pai VS. Differentiation of isolated and characterized human dental pulp stem cells and stem cells from human exfoliated deciduous teeth: An in vitro study. J Conservative Dentistry. 2013;16(5):423.

62. Saito S, Lin Y-C, Murayama Y, Hashimoto K, Yokoyama K. Human amnionderived cells as a reliable source of stem cells. Curr Mol Med. 2012;12(10): 1340-9.

63. Spitzhorn L-S, Rahman MS, Schwindt L, Ho H-T, Wruck W, Bohndorf M, Wehrmeyer S, Ncube A, Beyer I, Hagenbeck C. Isolation and molecular characterization of amniotic fluid-derived mesenchymal stem cells obtained from caesarean sections. Stem Cells International. 2017;2017.

64. Ankrum JA, Ong JF, Karp JM. Mesenchymal stem cells: immune evasive, not immune privileged. Nat Biotechnol. 2014;32(3):252.

65. de Souza Fernandez T, de Souza Fernandez C: Mesenchymal stem cells: biological characteristics and potential clinical applications for haematopoietic stem cell transplantation. In: Pluripotent Stem Cells-From the Bench to the Clinic. edn.: IntechOpen; 2016.

66. Ullah I, Subbarao RB, Rho GJ. Human mesenchymal stem cells-current trends and future prospective. Biosci Rep. 2015;35(2):e00191.

67. Hofer HR, Tuan RS. Secreted trophic factors of mesenchymal stem cells support neurovascular and musculoskeletal therapies. Stem Cell Res Ther. 2016;7(1):131.

68. Mea DN. Human bone marrow stromal cells suppress T-lymphocyte proliferation induced by cellular or nonspecific mitogenic stimuli. Blood. 2002;99:3838-43.

69. Spaggiari GM, Capobianco A, Becchetti S, Mingari MCM, L. Mesenchymal stem cell- natural killer cell interactions: evidence that activated NK cells are capable of killing MSCs, whereas MSCs can inhibit IL-2-induced NK-cell proliferation. Blood. 2006;107:1484-90.

70. Yagi HS-GA, Parekkadan B, Kitagawa Y, Tompkins RG, Kobayashi N, et al. Mesenchymal stem cells: mechanisms of immunomodulation and homing Cell Transplant. 2010;19:667-79.

71. Sun YQDM, He J, Zeng QX, Wen W, Wong DS, et al. Human pluripotent stem cell-derived mesenchymal stem cells prevent allergic airway inflammation in mice. Stem Cells. 2012;30:2692-9.

72. Chabannes DHM, Merieau E, Rossignol J, Brion R, Soulillou JP, et al. A role for heme oxygenase-1 in the immunosuppressive effect of adult rat and human mesenchymal stem cells. Blood. 2007;110:3691-4.

73. Fu QLCY, Sun SJ, Zeng QX, Li HB, Shi JB, et al. Mesenchymal stem cells derived from human induced pluripotent stem cells modulate T-cell phenotypes in allergic rhinitis. Allergy. 2012;67(10):1215-22.

74. Oryan A, Monazzah S, Bigham-Sadegh A. Bone injury and fracture healing biology. Biomed Environ Sci. 2015;28(1):57-71.

75. Porter JR, Ruckh TT, Popat KC. Bone tissue engineering: a review in bone biomimetics and drug delivery strategies. Biotechnol Prog. 2009;25(6):1539-60.

76. Downey PA, Siegel MI. Bone biology and the clinical implications for osteoporosis. Phys Ther. 2006;86(1):77-91.

77. Bigham-Sadegh A, Oryan A. Basic concepts regarding fracture healing and the current options and future directions in managing bone fractures. Int Wound J. 2015;12(3):238-47.

78. Florencio-Silva R, Sasso GRdS, Sasso-Cerri E, Simões MJ, Cerri PS: Biology of bone tissue: structure, function, and factors that influence bone cells. Biomed Res Int 2015, 2015.

79. Boskey AL, Coleman R. Aging and bone. J Dent Res. 2010;89(12):1333-48.

80. Mohamed AM. An overview of bone cells and their regulating factors of differentiation. Malaysian J Med Sci. 2008;15(1):4.

81. Salgado AJ, Coutinho OP, Reis RL. Bone tissue engineering: state of the art and future trends. Macromol Biosci. 2004;4(8):743-65.

82. Le BQ, Nurcombe V, Cool SM, Van Blitterswijk CA, De Boer J, LaPointe VLS. The components of bone and what they can teach us about regeneration. Materials. 2018;11(1):14.

83. Ibrahim A, Bulstrode N, Whitaker I, Eastwood D, Dunaway D, Ferretti P. Suppl-3, M5: nanotechnology for stimulating osteoprogenitor differentiation. Open Orthopaedics J. 2016;10:849.

84. Wiese A, Pape HC: Bone defects caused by high-energy injuries, bone loss, infected nonunions, and nonunions. Orthopedic Clin North Am 2010, 41(1): $1-4$, table of contents. 
85. Keller L, Regiel-Futyra A, Gimeno M, Eap S, Mendoza G, Andreu V, Wagner Q, Kyzioł A, Sebastian V, Stochel G. Chitosan-based nanocomposites for the repair of bone defects. Nanomedicine. 2017;13(7):2231-40.

86. Lichte $\mathrm{P}$, Pape $H$, Pufe T, Kobbe P, Fischer $H$. Scaffolds for bone healing: concepts, materials and evidence. Injury. 2011;42(6):569-73.

87. Newell N, Little J, Christou A, Adams M, Adam C, Masouros S. Biomechanics of the human intervertebral disc: a review of testing techniques and results. J Mech Behav Biomed Mater. 2017;69:420-34.

88. Bowles RD, Setton LA. Biomaterials for intervertebral disc regeneration and repair. Biomaterials. 2017;129:54-67.

89. Lotz J, Fields A, Liebenberg E. The role of the vertebral end plate in low back pain. Global spine journal. 2013;3(03):153-64.

90. Martins DE, de Medeiros VP, Wajchenberg M, Paredes-Gamero EJ, Lima M, Reginato RD, Nader HB, Puertas EB, Faloppa F: Changes in human intervertebral disc biochemical composition and bony end plates between middle and old age. PLoS One. 2018;13(9):e0203932.

91. Wang F, Cai F, Shi R, Wang X-H, Wu X-T. Aging and age related stresses: a senescence mechanism of intervertebral disc degeneration. Osteoarth Cartil. 2016;24(3):398-408

92. Haefeli M, Kalberer F, Saegesser D, Nerlich AG, Boos N, Paesold G. The course of macroscopic degeneration in the human lumbar intervertebral disc. Spine. 2006;31(14):1522-31.

93. Ito K, Creemers L. Mechanisms of intervertebral disk degeneration/injury and pain: a review. Global Spine J. 2013;3(3):145-51.

94. Jabłońska R, Ślusarz R, Królikowska A, Haor B, Antczak A, Szewczyk M Depression, social factors, and pain perception before and after surgery for lumbar and cervical degenerative vertebral disc disease. J Pain Res. 2017;10:89.

95. Sakai D, Nakamura Y, Nakai T, Mishima T, Kato S, Grad S, Alini M, Risbud MV, Chan D, Cheah KS. Exhaustion of nucleus pulposus progenitor cells with ageing and degeneration of the intervertebral disc. Nat Commun. 2012;3:1264

96. Sang C, Cao X, Chen F, Yang X, Zhang Y. Differential characterization of two kinds of stem cells isolated from rabbit nucleus pulposus and annulus fibrosus. Stem Cells Int. 2016;2016.

97. Liu L-T, Huang B, Li C-Q, Zhuang Y, Wang J, Zhou Y. Characteristics of stem cells derived from the degenerated human intervertebral disc cartilage endplate. PLoS One. 2011;6(10):e26285.

98. Illien-Jünger S, Pattappa G, Peroglio M, Benneker LM, Stoddart MJ, Sakai D, Mochida J, Grad S, Alini M. Homing of mesenchymal stem cells in induced degenerative intervertebral discs in a whole organ culture system. Spine. 2012;37(22):1865-73

99. Jin L, Liu Q, Scott P, Zhang D, Shen F, Balian G, Li X. Annulus fibrosus cell characteristics are a potential source of intervertebral disc pathogenesis. PLoS One. 2014;9(5):e96519.

100. Liang L, Li X, Li D, Jiang W, Wang H, Chen J, Sun Z, Zhang N, Zhu Y: The characteristics of stem cells in human degenerative intervertebral disc. Medicine (Baltimore). 2017;96(25):e7178.

101. Risbud MV, Guttapalli A, Tsai T-T, Lee JY, Danielson KG, Vaccaro AR, Albert TJ, Gazit Z, Gazit D, Shapiro IM. Evidence for skeletal progenitor cells in the degenerate human intervertebral disc. Spine. 2007;32(23):2537-44

102. Blanco JF, Graciani IF, Sanchez-Guijo FM, Muntión S, Hernandez-Campo P, Santamaria C, Carrancio S, Barbado M-V, Cruz G, Gutierrez-Cosío S. Isolation and characterization of mesenchymal stromal cells from human degenerated nucleus pulposus: comparison with bone marrow mesenchymal stromal cells from the same subjects. Spine. 2010;35(26): 2259-65.

103. Mao AS, Mooney DJ. Regenerative medicine: current therapies and future directions. Proc Natl Acad Sci. 2015;112(47):14452-9.

104. King RS, Newmark PA. The cell biology of regeneration. J Cell Biol. 2012; 196(5):553-62

105. Humzah M, Soames R. Human intervertebral disc: structure and function. Anat Rec. 1988;220(4):337-56.

106. Tzaan $\mathrm{W}-\mathrm{C}$, Chen $\mathrm{H}-\mathrm{C}$. Investigating the possibility of intervertebral disc regeneration induced by granulocyte colony stimulating factor-stimulated stem cells in rats. Advances Orthopedics. 2011;2011.

107. Henriksson HB, Svala E, Skioldebrand E, Lindahl A, Brisby H. Support of concept that migrating progenitor cells from stem cell niches contribute to normal regeneration of the adult mammal intervertebral disc: a descriptive study in the New Zealand white rabbit. Spine. 2012;37(9):722-32.

108. Sakai D, Nishimura K, Tanaka M, Nakajima D, Grad S, Alini M, Kawada H, Ando K, Mochida J. Migration of bone marrow-derived cells for endogenous repair in a new tail-looping disc degeneration model in the mouse: a pilot study. Spine J. 2015;15(6):1356-65.

109. Cunha C, Almeida CR, Almeida MI, Silva AM, Molinos M, Lamas S, Pereira CL, Teixeira GQ, Monteiro AT, Santos SG. Systemic delivery of bone marrow mesenchymal stem cells for in situ intervertebral disc regeneration. Stem Cells Transl Med. 2017;6(3):1029-39.

110. Sheikh H, Zakharian K, De La Torre RP, Facek C, Vasquez A, Chaudhry GR, Svinarich D, Perez-Cruet MJ. In vivo intervertebral disc regeneration using stem cell-derived chondroprogenitors. J Neurosurg Spine. 2009;10(3):26572.

111. Beeravolu N, Brougham J, Khan I, McKee C, Perez-Cruet M, Chaudhry GR. Human umbilical cord derivatives regenerate intervertebral disc. J Tissue Eng Regen Med. 2018;12(1):e579-91.

112. Sakai D, Schol J. Cell therapy for intervertebral disc repair: clinical perspective. J Orthopaedic Translation. 2017:9:8-18.

113. Gou S, Oxentenko SC, Eldrige JS, Xiao L, Pingree MJ, Wang Z, Perez-Terzic C, Qu W. Stem cell therapy for intervertebral disk regeneration. Am J Physical Med Rehabilitation. 2014;93(11):S122-31.

114. Richardson SM, Curran JM, Chen R, Vaughan-Thomas A, Hunt JA, Freemont AJ, Hoyland JA. The differentiation of bone marrow mesenchymal stem cells into chondrocyte-like cells on poly-L-lactic acid (PLLA) scaffolds. Biomaterials. 2006;27(22):4069-78.

115. Zhang Z, Li F, Tian H, Guan K, Zhao G, Shan J, Ren D. Differentiation of adipose-derived stem cells toward nucleus pulposus-like cells induced by hypoxia and a three-dimensional chitosan-alginate gel scaffoldin vitro. Chin Med J. 2014;127(2):314-21.

116. Revell P, Damien E, Di Silvio L, Gurav N, Longinotti C, Ambrosio L. Tissue engineered intervertebral disc repair in the pig using injectable polymers. J Mater Sci Mater Med. 2007;18(2):303-8.

117. Smith LJ, Gorth DJ, Showalter BL, Chiaro JA, Beattie EE, Elliott DM, Mauck RL, Chen W, Malhotra NR. In vitro characterization of a stem-cell-seeded tripleinterpenetrating-network hydrogel for functional regeneration of the nucleus pulposus. Tissue Eng A. 2014;20(13-14):1841-9.

118. Teixeira GQ, Boldt A, Nagl I, Pereira CL, Benz K, Wilke H-J, Ignatius A, Barbosa MA, Gonçalves RM, Neidlinger-Wilke C. A degenerative/proinflammatory intervertebral disc organ culture: An ex vivo model for anti-inflammatory drug and cell therapy. Tissue Engineering Part C: Methods. 2015;22(1):8-19.

119. Sun Z, Luo B, Liu Z-H, Samartzis D, Liu Z, Gao B, Huang L, Luo Z-J. Adipose-derived stromal cells protect intervertebral disc cells in compression: implications for stem cell regenerative disc therapy. Int J Biol Sci. 2015;11(2):133.

120. Chanda D, Kumar S, Ponnazhagan S. Therapeutic potential of adult bone marrow-derived mesenchymal stem cells in diseases of the skeleton. J Cell Biochem. 2010;111(2):249-57.

121. Yoshikawa T, Ueda Y, Miyazaki K, Koizumi M, Takakura Y. Disc regeneration therapy using marrow mesenchymal cell transplantation: a report of two case studies. Spine. 2010;35(11):E475-80.

122. Sakai D, Mochida J, Yamamoto Y, Nomura T, Okuma M, Nishimura K, Nakai T, Ando K, Hotta T. Transplantation of mesenchymal stem cells embedded in Atelocollagen ${ }^{\oplus}$ gel to the intervertebral disc: a potential therapeutic model for disc degeneration. Biomaterials. 2003;24(20):3531-41.

123. Li X, Lee JP, Balian G, Greg Anderson D. Modulation of chondrocytic properties of fat-derived mesenchymal cells in co-cultures with nucleus pulposus. Connect Tissue Res. 2005;46(2):75-82.

124. Gaetani P, Torre ML, Klinger M, Faustini M, Crovato F, Bucco M, Marazzi M, Chlapanidas T, Levi D, Tancioni F. Adipose-derived stem cell therapy for intervertebral disc regeneration: an in vitro reconstructed tissue in alginate capsules. Tissue Eng A. 2008;14(8):1415-23.

125. Vadalà G, Sobajima S, Lee JY, Huard J, Denaro V, Kang JD, Gilbertson LG. In vitro interaction between muscle-derived stem cells and nucleus pulposus cells. Spine J. 2008;8(5):804-9.

126. Murrell W, Sanford E, Anderberg L, Cavanagh B, Mackay-Sim A. Olfactory stem cells can be induced to express chondrogenic phenotype in a rat intervertebral disc injury model. Spine J. 2009:9(7):585-94.

127. Miyamoto T, Muneta T, Tabuchi T, Matsumoto K, Saito H, Tsuji K, Sekiya I. Intradiscal transplantation of synovial mesenchymal stem cells prevents intervertebral disc degeneration through suppression of matrix metalloproteinase-related genes in nucleus pulposus cells in rabbits. Arthritis Res Therapy. 2010;12(6):R206.

128. Antebi B, Pelled G, Gazit D. Stem cell therapy for osteoporosis. Current Osteoporosis Reports. 2014;12(1):41-7. 
129. Langdahl B, Ferrari S, Dempster DW. Bone modeling and remodeling: potential as therapeutic targets for the treatment of osteoporosis. Therapeutic Advances Musculoskeletal Disease. 2016;8(6):225-35.

130. Sanghani-Kerai A, Osagie-Clouard L, Blunn G, Coathup M. The influence of age and osteoporosis on bone marrow stem cells from rats. Bone Joint Research. 2018;7(4):289-97.

131. Tu KN, Lie JD, Wan CKV, Cameron M, Austel AG, Nguyen JK, Van K, Hyun D. Osteoporosis: a review of treatment options. Pharmacy Therapeutics. 2018; 43(2):92.

132. Catalano A, Martino G, Morabito N, Scarcella C, Gaudio A, Basile G, Lasco A. Pain in osteoporosis: from pathophysiology to therapeutic approach. Drugs Aging. 2017;34(10):755-65

133. Weinstein RS, Roberson PK, Manolagas SC. Giant osteoclast formation and long-term oral bisphosphonate therapy. N Engl J Med. 2009;360(1):53-62.

134. Khan AA, Sándor GK, Dore E, Morrison AD, Alsahli M, Amin F, Peters E, Hanley DA, Chaudry SR, Lentle B. Bisphosphonate associated osteonecrosis of the jaw. J Rheumatol. 2009;36(3):478-90.

135. Lo JC, O'Ryan FS, Gordon NP, Yang J, Hui RL, Martin D, Hutchinson M, Lathon PV, Sanchez G, Silver P. Prevalence of osteonecrosis of the jaw in patients with oral bisphosphonate exposure. J Oral Maxillofac Surg. 2010; 68(2):243-53.

136. Yao W, Guan M, Jia J, Dai W, Lay YAE, Amugongo S, Liu R, Olivos D, Saunders M, Lam KS. Reversing bone loss by directing mesenchymal stem cells to bone. Stem Cells. 2013;31(9):2003-14.

137. Black DM, Bilezikian JP, Ensrud KE, Greenspan SL, Palermo L, Hue T, Lang TF, McGowan JA, Rosen CJ. One year of alendronate after one year of parathyroid hormone (1-84) for osteoporosis. N Engl J Med. 2005;353(6):555-65.

138. Canalis E, Giustina A, Bilezikian JP. Mechanisms of anabolic therapies for osteoporosis. N Engl J Med. 2007;357(9):905-16.

139. Ichioka N, Inaba M, Kushida T, Esumi T, Takahara K, Inaba K, Ogawa R, lida $\mathrm{H}$, Ikehara S. Prevention of senile osteoporosis in SAMP6 mice by intrabone marrow injection of allogeneic bone marrow cells. Stem Cells. 2002;20(6):542-51

140. Ocarino NdM, Boeloni JN, Jorgetti V, Gomes DA, Goes AM, Serakides R: Intra-bone marrow injection of mesenchymal stem cells improves the femur bone mass of osteoporotic female rats. Connect Tissue Res 2010, 51(6):426-433

141. Wang Z, Goh J, De SD, Ge Z, Ouyang H, Chong JSW, Low SL, Lee EH. Efficacy of bone marrow-derived stem cells in strengthening osteoporotic bone in a rabbit model. Tissue Eng. 2006;12(7):1753-61.

142. Stolzing A, Jones E, McGonagle D, Scutt A. Age-related changes in human bone marrow-derived mesenchymal stem cells: consequences for cell therapies. Mech Ageing Dev. 2008;129(3):163-73.

143. Sui B, Hu C, Zhang X, Zhao P, He T, Zhou C, Qiu X, Chen N, Zhao X, Jin Y. Allogeneic mesenchymal stem cell therapy promotes osteoblastogenesis and prevents glucocorticoid-induced osteoporosis. Stem Cells Transl Med. 2016;5(9):1238-46.

144. Lozano-Rivas N, Linares L, Marras-Fernandez-Cid C, Garcia-Hernandez A, Alqueró M, Iniesta F, Sanchez-Salinas D, López-Lucas M, Rodriguez-Valiente M, Cabañas V: AB1011 clinical trial of intravenous infusion of fucosylated bone marrow mesenchymal stem cells in patients with osteoporosis. In.: BMJ Publishing Group Ltd; 2018.

145. Bieback K, Brinkmann I. Mesenchymal stromal cells from human perinatal tissues: from biology to cell therapy. World J Stem Cells. 2010;2(4):81.

146. Saito A, Nagaishi K, Iba K, Mizue Y, Chikenji T, Otani M, Nakano M, Oyama K, Yamashita T, Fujimiya M. Umbilical cord extracts improve osteoporotic abnormalities of bone marrow-derived mesenchymal stem cells and promote their therapeutic effects on ovariectomised rats. Sci Rep. 2018;8(1):1161.

147. An JH, Park H, Song JA, Ki KH, Yang J-Y, Choi HJ, Cho SW, Kim SW, Kim SY, Yoo JJ. Transplantation of human umbilical cord blood-derived mesenchymal stem cells or their conditioned medium prevents bone loss in ovariectomized nude mice. Tissue Eng A. 2013;19(5-6):685-96.

148. Fu Y-S, Lu C-H, Chu K-A, Yeh C-C, Chiang T-L, Ko T-L, Chiu M-M, Chen C-F. Xenograft of human umbilical mesenchymal stem cells from Wharton's jelly differentiating into osteocytes and reducing osteoclast activity reverses osteoporosis in ovariectomized rats. Cell Transplant. 2018;27(1):194-208.

149. Hendrijantini N, Kusumaningsih T, Rostiny R, Mulawardhana P, Danudiningrat CP, Rantam FA. A potential therapy of human umbilical cord mesenchymal stem cells for bone regeneration on osteoporotic mandibular bone. Eur J Dentistry. 2018;12(3):358.
150. Langdahl BL, Carstens M, Stenkjær L, Eriksen EF. Polymorphisms in the transforming growth factor beta 1 gene and osteoporosis. Bone. 2003;32(3): 297-310.

151. Pino AM, Rosen CJ, Rodríguez JP. In osteoporosis, differentiation of mesenchymal stem cells (MSCs) improves bone marrow adipogenesis. Biol Res. 2012:45(3):279-87.

152. Prall WC, Haasters F, Heggebö J, Polzer H, Schwarz C, Gassner C, Grote S, Anz D, Jäger M, Mutschler W. Mesenchymal stem cells from osteoporotic patients feature impaired signal transduction but sustained osteoinduction in response to BMP-2 stimulation. Biochem Biophys Res Commun. 2013; 440(4):617-22.

153. Kern S, Eichler H, Stoeve J, Klüter H, Bieback K. Comparative analysis of mesenchymal stem cells from bone marrow, umbilical cord blood, or adipose tissue. Stem Cells. 2006;24(5):1294-301.

154. Chen HT, Lee MJ, Chen CH, Chuang SC, Chang LF, Ho ML, Hung SH, Fu YC, Wang $\mathrm{YH}$, Wang $\mathrm{HI}$. Proliferation and differentiation potential of human adipose-derived mesenchymal stem cells isolated from elderly patients with osteoporotic fractures. J Cell Mol Med. 2012;16(3):582-92.

155. Zheng C-X, Sui B-D, Liu N, Hu C-H, He T, Zhang X-Y, Zhao P, Chen J, Xuan K Jin $Y$. Adipose mesenchymal stem cells from osteoporotic donors preserve functionality and modulate systemic inflammatory microenvironment in osteoporotic cytotherapy. Sci Rep. 2018;8(1):5215.

156. Oommen A, Al-Zahrani IH. Effect of adipose derived stem cells on ovariectomised Wistar rats. Int J Res Med Sci. 2017;3(11):3224-9.

157. Wang C, Meng H, Wang X, Zhao C, Peng J, Wang Y. Differentiation of bone marrow mesenchymal stem cells in osteoblasts and adipocytes and its role in treatment of osteoporosis. Med Sci Monitor. 2016;22:226.

158. Lien CY, Chih-Yuan Ho K, Lee OK, Blunn GW, Su Y. Restoration of bone mass and strength in glucocorticoid-treated mice by systemic transplantation of CXCR4 and cbfa-1 co-expressing mesenchymal stem cells. J Bone Miner Res. 2009;24(5):837-48

159. Li X, Bai J, Ji X, Li R, Xuan Y, Wang Y. Comprehensive characterization of four different populations of human mesenchymal stem cells as regards their immune properties, proliferation and differentiation. Int J Mol Med. 2014;34(3):695-704.

160. Phetfong J, Sanvoranart T, Nartprayut K, Nimsanor N, Seenprachawong K, Prachayasittikul V, Supokawej A. Osteoporosis: the current status of mesenchymal stem cell-based therapy. Cellular Molecular Biology Letters. 2016;21(1):12

161. Vanleene M, Saldanha Z, Cloyd KL, Jell G, Bou-Gharios G, Bassett JD, Williams GR, Fisk NM, Oyen ML, Stevens MM. Transplantation of human fetal blood stem cells in the osteogenesis imperfecta mouse leads to improvement in multiscale tissue properties. Blood. 2011;117(3):1053-60.

162. Horwitz EM, Gordon PL, Koo WK, Marx JC, Neel MD, McNall RY, Muul L, Hofmann T. Isolated allogeneic bone marrow-derived mesenchymal cells engraft and stimulate growth in children with osteogenesis imperfecta: implications for cell therapy of bone. Proc Natl Acad Sci. 2002;99(13):8932-7.

163. Le Blanc K, Götherström C, Ringdén O, Hassan M, McMahon R, Horwitz E, Anneren G, Axelsson O, Nunn J, Ewald U. Fetal mesenchymal stem-cell engraftment in bone after in utero transplantation in a patient with severe osteogenesis imperfecta. Transplantation. 2005;79(11):1607-14.

164. Guillot PV, Abass O, Bassett JD, Shefelbine SJ, Bou-Gharios G, Chan J, Kurata H, Williams GR, Polak J, Fisk NM. Intrauterine transplantation of human fetal mesenchymal stem cells from first-trimester blood repairs bone and reduces fractures in osteogenesis imperfecta mice. Blood. 2008;111(3):1717-25.

165. Ghiasi MS, Chen J, Vaziri A, Rodriguez EK, Nazarian A. Bone fracture healing in mechanobiological modeling: a review of principles and methods. Bone Reports. 2017;6:87-100..

166. Ho-Shui-Ling A, Bolander J, Rustom LE, Johnson AW, Luyten FP, Picart C. Bone regeneration strategies: engineered scaffolds, bioactive molecules and stem cells current stage and future perspectives. Biomaterials. 2018.

167. Kolar P, Schmidt-Bleek K, Schell H, Gaber T, Toben D, Schmidmaier G, Perka C, Buttgereit F, Duda GN. The early fracture hematoma and its potential role in fracture healing. Tissue Eng B Rev. 2010;16(4):427-34.

168. Albrektsson T, Johansson C. Osteoinduction, osteoconduction and osseointegration. Eur Spine J. 2001;10(2):S96-S101.

169. Wang W, Yeung KW. Bone grafts and biomaterials substitutes for bone defect repair: a review. Bioactive Materials. 2017;2(4):224-47.

170. Campana V, Milano G, Pagano E, Barba M, Cicione C, Salonna G, Lattanzi W, Logroscino G. Bone substitutes in orthopaedic surgery: from basic science to clinical practice. J Mater Sci Mater Med. 2014;25(10): 2445-61. 
171. Gómez-Barrena E, Rosset P, Lozano D, Stanovici J, Ermthaller C, Gerbhard F. Bone fracture healing: cell therapy in delayed unions and nonunions. Bone. 2015;70:93-101.

172. Fernandez de Grado G, Keller L, Idoux-Gillet Y, Wagner Q, Musset A-M, Benkirane-Jessel N, Bornert F, Offner D: Bone substitutes: a review of their characteristics, clinical use, and perspectives for large bone defects management. J Tissue Eng 2018, 9:2041731418776819.

173. Langer RVJ. Tissue engineering. Science. 1993;260:920-6.

174. Giannoudis PV, Einhorn TA, Marsh D. Fracture healing: the diamond concept. Injury. 2007;38:S3-6.

175. Calabrese G, Giuffrida R, Forte S, Fabbi C, Figallo E, Salvatorelli L, Memeo L, Parenti R, Gulisano M, Gulino R. Human adipose-derived mesenchymal stem cells seeded into a collagen-hydroxyapatite scaffold promote bone augmentation after implantation in the mouse. Sci Rep. 2017;7(1):7110.

176. Maiti SK, Shivakumar M, Mohan D, Kumar N, Singh KP. Mesenchymal stem cells of different origin-seeded bioceramic construct in regeneration of bone defect in rabbit. Tissue Eng Regenerative Medicine. 2018;15(4):477-92.

177. Granero-Moltó F, Weis JA, Miga MI, Landis B, Myers TJ, O'Rear L, Longobardi $L$, Jansen ED, Mortlock DP, Spagnoli A. Regenerative effects of transplanted mesenchymal stem cells in fracture healing. Stem Cells. 2009;27(8):1887-98.

178. Jang B-J, Byeon Y-E, Lim J-H, Ryu H-H, Kim WH, Koyama Y, Kikuchi M, Kang K-S, Kweon O-K. Implantation of canine umbilical cord blood-derived mesenchymal stem cells mixed with beta-tricalcium phosphate enhances osteogenesis in bone defect model dogs. J Vet Sci. 2008;9(4):387-93.

179. Colnot C. Skeletal cell fate decisions within periosteum and bone marrow during bone regeneration. J Bone Miner Res. 2009;24(2):274-82.

180. Devine MJ, Mierisch CM, Jang E, Anderson PC, Balian G. Transplanted bone marrow cells localize to fracture callus in a mouse model. J Orthop Res. 2002;20(6):1232-9.

181. Oryan A, Kamali A, Moshiri A, Eslaminejad MB. Role of mesenchymal stem cells in bone regenerative medicine: what is the evidence? Cells Tissues Organs. 2017;204(2):59-83.

182. De Witte T-M, Fratila-Apachitei LE, Zadpoor AA, Peppas NA. Bone tissue engineering via growth factor delivery: from scaffolds to complex matrices. Regenerative Biomaterials. 2018;5(4):197-211.

183. Marcacci M, Kon E, Moukhachev V, Lavroukov A, Kutepov S, Quarto R, Mastrogiacomo M, Cancedda R. Stem cells associated with macroporous bioceramics for long bone repair: 6-to 7-year outcome of a pilot clinical study. Tissue Eng. 2007;13(5):947-55.

184. Langevin HM. Connective tissue: a body-wide signaling network? Med Hypotheses. 2006;66(6):1074-7.

185. Pap T, Korb-Pap A. Cartilage damage in osteoarthritis and rheumatoid arthritis - two unequal siblings. Nat Rev Rheumatol. 2015;11(10):606

186. Randolph MA, Anseth K, Yaremchuk MJ. Tissue engineering of cartilage. Clin Plast Surg. 2003;30(4):519-37.

187. Oseni AO, Crowley C, Boland MZ, Butler PE, Seifalian AM. Cartilage tissue engineering: the application of nanomaterials and stem cell technology. Tissue Eng Tissue Organ Regeneration. 2011;1:233-67.

188. Sophia Fox AJ, Bedi A, Rodeo SA. The basic science of articular cartilage: structure, composition, and function. Sports Health. 2009;1(6):461-8.

189. Glyn-Jones S, Palmer A, Agricola R, Price A, Vincent T, Weinans H, Carr A Osteoarthritis. Lancet. 2015;386(9991):376-87.

190. Li Y, Wei X, Zhou J, Wei L. The age-related changes in cartilage and osteoarthritis. Biomed Res Int. 2013;2013:916530.

191. Loeser RF. Molecular mechanisms of cartilage destruction: mechanics, inflammatory mediators, and aging collide. Arthritis Rheumatism. 2006;54(5): 1357-60.

192. Loeser RF, Goldring SR, Scanzello CR, Goldring MB. Osteoarthritis: a disease of the joint as an organ. Arthritis Rheumatism. 2012;64(6):1697-707.

193. Marcacci M, Filardo G, Kon E. Treatment of cartilage lesions: what works and why? Injury. 2013;44:S11-5

194. Zhang W, Ouyang H, Dass CR, Xu J. Current research on pharmacologic and regenerative therapies for osteoarthritis. Bone Research. 2016;4:15040.

195. Lee KM, Chung CY, Sung KH, Lee SY, Won SH, Kim TG, Choi Y, Kwon S-S, Kim $\mathrm{YH}$, Park MS. Risk factors for osteoarthritis and contributing factors to current arthritic pain in South Korean older adults. Yonsei Med J. 2015;56(1):124-31.

196. Zhang W, Moskowitz R, Nuki G, Abramson S, Altman R, Arden N, Bierma-Zeinstra S, Brandt K, Croft P, Doherty M. OARSI recommendations for the management of hip and knee osteoarthritis, part II: OARSI evidence-based, expert consensus quidelines. Osteoarthr Cartil. 2008;16(2):137-62.
197. Jevsevar DS. Treatment of osteoarthritis of the knee: evidence-based guideline. J Am Acad Orthopaedic Surg. 2013;21(9):571-6.

198. Whitney KE, Liebowitz A, Bolia IK, Chahla J, Ravuri S, Evans TA, Philippon MJ, Huard J. Current perspectives on biological approaches for osteoarthritis. Ann N Y Acad Sci. 2017;1410(1):26-43.

199. Toh WS, Lai RC, Hui JHP, Lim SK: MSC exosome as a cell-free MSC therapy for cartilage regeneration: implications for osteoarthritis treatment. In: Seminars in cell \& developmental biology: 2017: Elsevier; 2017: 56-64.

200. Li M, Luo X, Lv X, Liu V, Zhao G, Zhang X, Cao W, Wang R, Wang W. In vivo human adipose-derived mesenchymal stem cell tracking after intra-articular delivery in a rat osteoarthritis model. Stem Cell Res Ther. 2016;7(1):160.

201. Desando G, Giavaresi G, Cavallo C, Bartolotti I, Sartoni F, Nicoli Aldini N, Martini L, Parrilli A, Mariani E, Fini M. Autologous bone marrow concentrate in a sheep model of osteoarthritis: new perspectives for cartilage and meniscus repair. Tissue Engineering Part C: Methods. 2016;22(6):608-19.

202. Jones EA, Crawford A, English A, Henshaw K, Mundy J, Corscadden D, Chapman T, Emery P, Hatton P, McGonagle D. Synovial fluid mesenchymal stem cells in health and early osteoarthritis: detection and functional evaluation at the single-cell level. Arthritis Rheumatism. 2008;58(6):1731-40.

203. Park YB, Song M, Lee CH, Kim JA, Ha CW. Cartilage repair by human umbilical cord blood-derived mesenchymal stem cells with different hydrogels in a rat model. J Orthop Res. 2015;33(11):1580-6.

204. Liu S, Jia Y, Yuan M, Guo W, Huang J, Zhao B, Peng J, Xu W, Lu S, Guo Q. Repair of osteochondral defects using human umbilical cord Wharton's jelly-derived mesenchymal stem cells in a rabbit model. Biomed Res Int. 2017;2017.

205. Youssef A, Aboalola D, Han VK. The roles of insulin-like growth factors in mesenchymal stem cell niche. Stem Cells Int. 2017;2017.

206. Satué M, Schüler C, Ginner N, Erben RG. Intra-articularly injected mesenchymal stem cells promote cartilage regeneration, but do not permanently engraft in distant organs. Sci Rep. 2019;9(1):1-10.

207. Chahal J, Gómez-Aristizábal A, Shestopaloff K, Bhatt S, Chaboureau A, Fazio A, Chisholm J, Weston A, Chiovitti J, Keating A. Bone marrow mesenchymal stromal cell treatment in patients with osteoarthritis results in overall improvement in pain and symptoms and reduces synovial inflammation. Stem Cells Transl Med. 2019:8(8):746-57.

208. Gao J, Dennis JE, Solchaga LA, Awadallah AS, Goldberg VM, Caplan Al. Tissueengineered fabrication of an osteochondral composite graft using rat bone marrow-derived mesenchymal stem cells. Tissue Eng. 2001;7(4):363-71.

209. Muñoz-Criado I, Meseguer-Ripolles J, Mellado-López M, Alastrue-Agudo A, Griffeth RJ, Forteza-Vila J, Cugat R, García M, Moreno-Manzano V. Human suprapatellar fat pad-derived mesenchymal stem cells induce chondrogenesis and cartilage repair in a model of severe osteoarthritis. Stem Cells Int. 2017;2017:4758930.

210. Song Y, Du H, Dai C, Zhang L, Li S, Hunter DJ, Lu L, Bao C. Human adipose-derived mesenchymal stem cells for osteoarthritis: a pilot study with long-term follow-up and repeated injections. Regen Med. 2018; 13(3):295-307.

211. Kim J-H, Jo CH, Kim H-R, Y-i H. Comparison of immunological characteristics of mesenchymal stem cells from the periodontal ligament, umbilical cord, and adipose tissue. Stem Cells Int. 2018:2018:8429042.

212. Yang $S$, Ha C, Jung $M$, Jin $H$, Lee $M$, Song $H$, Choi $S$, Oh W, Yang $Y$. Mesenchymal stem/progenitor cells developed in cultures from UC blood. Cytotherapy. 2004;6(5):476-86.

213. Troyer DL, Weiss ML. Concise review: Wharton's jelly-derived cells are a primitive stromal cell population. Stem Cells. 2008;26(3):591-9.

214. Liu S, Hou KD, Yuan M, Peng J, Zhang L, Sui X, Zhao B, Xu W, Wang A, Lu S. Characteristics of mesenchymal stem cells derived from Wharton's jelly of human umbilical cord and for fabrication of non-scaffold tissue-engineered cartilage. J Biosci Bioeng. 2014;117(2):229-35.

215. Ding Y, Bushell A, Wood KJ. Mesenchymal stem-cell immunosuppressive capabilities: therapeutic implications in islet transplantation. Transplantation. 2010;89(3):270.

216. Kourilovitch M, Galarza-Maldonado C, Ortiz-Prado E. Diagnosis and classification of rheumatoid arthritis. J Autoimmun. 2014;48:26-30.

217. Shadmanfar S, Labibzadeh N, Emadedin M, Jaroughi N, Azimian V, Mardpour S, Kakroodi FA, Bolurieh T, Hosseini SE, Chehrazi M. Intra-articular knee implantation of autologous bone marrow-derived mesenchymal stromal cells in rheumatoid arthritis patients with knee involvement: results of a randomized, triple-blind, placebo-controlled phase 1/2 clinical trial. Cytotherapy. 2018;20(4):499-506. 
218. Djouad F, Bouffi C, Ghannam S, Noël D, Jorgensen C. Mesenchymal stem cells: innovative therapeutic tools for rheumatic diseases. Nat Rev Rheumatol. 2009;5(7):392.

219. Lopez-Santalla M, Mancheño-Corvo P, Menta R, Lopez-Belmonte J, DelaRosa O, Bueren JA, Dalemans W, Lombardo E, Garin MI. Human adipose-derived mesenchymal stem cells modulate experimental autoimmune arthritis by modifying early adaptive T cell responses. Stem Cells. 2015;33(12):3493-503.

220. Liu R, Li X, Zhang Z, Zhou M, Sun Y, Su D, Feng X, Gao X, Shi S, Chen W. Allogeneic mesenchymal stem cells inhibited T follicular helper cell generation in rheumatoid arthritis. Sci Rep. 2015;5:12777.

221. Gu Y, Shi S. Transplantation of gingiva-derived mesenchymal stem cells ameliorates collagen-induced arthritis. Arthritis Research Therapy. 2016; 18(1):262.

222. Gonzalez-Rey E, Gonzalez MA, Varela N, O'Valle F, Hernandez-Cortes P, Rico $L$, Büscher D, Delgado M. Human adipose-derived mesenchymal stem cells reduce inflammatory and $T$ cell responses and induce regulatory $T$ cells in vitro in rheumatoid arthritis. Ann Rheum Dis. 2010;69(01):241-8.

223. Kehoe O, Cartwright A, Askari A, El Haj AJ, Middleton J. Intra-articular injection of mesenchymal stem cells leads to reduced inflammation and cartilage damage in murine antigen-induced arthritis. J Transl Med. 2014;12(1):157.

224. Park EH, Lim HS, Lee S, Roh K, Seo KW, Kang KS, Shin K. Intravenous infusion of umbilical cord blood-derived mesenchymal stem cells in rheumatoid arthritis: a phase la clinical trial. Stem Cells Transl Med. 2018;7(9):636-42.

225. Hirayama T, Danks L, Sabokbar A, Athanasou N. Osteoclast formation and activity in the pathogenesis of osteoporosis in rheumatoid arthritis. Rheumatology. 2002;41(11):1232-9.

226. Luo Y, Wu W, Gu J, Zhang X, Dang J, Wang J, Zheng Y, Huang F, Yuan J, Xue $Y$. Human gingival tissue-derived MSC suppress osteoclastogenesis and bone erosion via CD39-adenosine signal pathway in autoimmune arthritis. EBioMedicine. 2019;43:620-31.

227. Zhang L, Wang X-Y, Zhou P-J, He Z, Yan H-Z, Xu D-D, Wang Y, Fu W-Y, Ruan $B-B$, Wang $S$. Use of immune modulation by human adipose-derived mesenchymal stem cells to treat experimental arthritis in mice. Am J Transl Res. 2017:9(5):2595.

228. DelaRosa O, Lombardo E. Modulation of adult mesenchymal stem cells activity by toll-like receptors: implications on therapeutic potential. Mediat Inflamm. 2010;2010.

229. Pitchford SC, Furze RC, Jones CP, Wengner AM, Rankin SM. Differential mobilization of subsets of progenitor cells from the bone marrow. Cell Stem Cell. 2009:4(1):62-72.

230. de Girolamo L, Lucarelli E, Alessandri G, Antonietta Avanzini M, Ester Bernardo M, Biagi E, Teresa Brini A, D'Amico G, Fagioli F, Ferrero I: Mesenchymal stem/stromal cells: a new "cells as drugs" paradigm. Efficacy and critical aspects in cell therapy. Curr Pharm Des 2013, 19(13):2459-2473.

231. Qin Y, Guan J, Zhang C. Mesenchymal stem cells: mechanisms and role in bone regeneration. Postgrad Med J. 2014;90(1069):643-7.

232. Lin W, Xu L, Zwingenberger S, Gibon E, Goodman SB, Li G. Mesenchymal stem cells homing to improve bone healing. J Orthopaedic Translation. 2017:9:19-27.

233. Su P, Tian Y, Yang C, Ma X, Wang X, Pei J, Qian A. Mesenchymal stem cell migration during bone formation and bone diseases therapy. Int J Mol Sci. 2018;19(8):2343.

234. Caplan Al, Correa D. PDGF in bone formation and regeneration: new insights into a novel mechanism involving MSCs. J Orthop Res. 2011;29(12): $1795-803$.

235. Li A, Xia X, Yeh J, Kua H, Liu H, Mishina Y, Hao A, Li B: PDGF-AA promotes osteogenic differentiation and migration of mesenchymal stem cell by down-regulating PDGFRa and derepressing BMP-Smad1/5/8 signaling. PLoS One 2014;9(12):e113785.

236. Liu H, Xue W, Ge G, Luo X, Li Y, Xiang H, Ding X, Tian P, Tian X. Hypoxic preconditioning advances CXCR4 and CXCR7 expression by activating HIF1a in MSCs. Biochem Biophys Res Commun. 2010;401(4):509-15.

237. Xu G, Xue M, Wang H, Xiang C. Hypoxia-inducible factor-1a antagonizes the hypoxia-mediated osteoblast cell viability reduction by inhibiting apoptosis. Experimental Therapeutic Med. 2015;9(5):1801-6.

238. Toupadakis CA, Wong A, Genetos DC, Chung DJ, Murugesh D, Anderson MJ, Loots GG, Christiansen BA, Kapatkin AS, Yellowley CE. Long-term administration of AMD3100, an antagonist of SDF-1/CXCR4 signaling, alters fracture repair. J Orthop Res. 2012;30(11):1853-9.

239. Zwingenberger S, Yao Z, Jacobi A, Vater C, Valladares RD, Li C, Nich C, Rao AJ, Christman JE, Antonios JK. Enhancement of BMP-2 induced bone regeneration by SDF-1a mediated stem cell recruitment. Tissue Eng A. 2013; 20(3-4):810-8.

240. Kitaori T, Ito H, Schwarz EM, Tsutsumi R, Yoshitomi H, Oishi S, Nakano M, Fujii N, Nagasawa T, Nakamura T. Stromal cell-derived factor 1/CXCR4 signaling is critical for the recruitment of mesenchymal stem cells to the fracture site during skeletal repair in a mouse model. Arthritis Rheumatism. 2009;60(3):813-23.

241. Wang Y, Xu J, Zhang X, Wang C, Huang Y, Dai K, Zhang X. TNF-a-induced LRG1 promotes angiogenesis and mesenchymal stem cell migration in the subchondral bone during osteoarthritis. Cell Death Dis. 2017;8(3):e2715.

242. Oshima Y, Watanabe N, Matsuda K-I, Takai S, Kawata M, Kubo T. Behavior of transplanted bone marrow-derived GFP mesenchymal cells in osteochondral defect as a simulation of autologous transplantation. J Histochemistry Cytochemistry. 2005;53(2):207-16.

243. Mohyeldin A, Garzón-Muvdi T, Quiñones-Hinojosa A. Oxygen in stem cell biology: a critical component of the stem cell niche. Cell Stem Cell. 2010; 7(2):150-61

244. Kagiwada H, Yashiki T, Ohshima A, Tadokoro M, Nagaya N, Ohgushi H. Human mesenchymal stem cells as a stable source of VEGF-producing cells. J Tissue Eng Regen Med. 2008;2(4):184-9.

245. Kovach TK, Dighe AS, Lobo PI, Cui Q. Interactions between MSCs and immune cells: implications for bone healing. J Immunol Res. 2015;2015.

246. Smadja D, d'Audigier C, Guerin C, Mauge L, Dizier B, Silvestre J, Dal Cortivo L, Gaussem P, Emmerich J. Angiogenic potential of BM MSCs derived from patients with critical leg ischemia. Bone Marrow Transplant. 2012;47(7):997.

247. Oki N, Abe T, Kunimatsu R, Sumi K, Awada T, Tsuka Y, Nakajima K, Ando K, Tanimoto $K$. The role of vascular endothelial growth factor and mesenchymal stem cells during angiogenesis. Biomed Res. 2018;29(15): 3079-84.

248. Tirpe AA, Gulei D, Ciortea SM, Crivii C, Berindan-Neagoe I. Hypoxia: overview on hypoxia-mediated mechanisms with a focus on the role of HIF genes. Int J Mol Sci. 2019;20(24):6140.

249. Ferrara N. Molecular and biological properties of vascular endothelial growth factor. J Mol Med. 1999;77(7):527-43.

250. Riddle RC, Khatri R, Schipani E, Clemens TL. Role of hypoxia-inducible factor1a in angiogenic-osteogenic coupling. J Mol Med. 2009;87(6):583-90.

251. Claes L, Recknagel S, Ignatius A. Fracture healing under healthy and inflammatory conditions. Nat Rev Rheumatol. 2012;8(3):133.

252. Baht GS, Vi L, Alman BA. The role of the immune cells in fracture healing. Current Osteoporosis Reports. 2018;16(2):138-45.

253. Yoo KH, Jang IK, Lee MW, Kim HE, Yang MS, Eom Y, Lee JE, Kim YJ, Yang SK, Jung HL. Comparison of immunomodulatory properties of mesenchymal stem cells derived from adult human tissues. Cell Immunol. 2009;259(2): 150-6.

254. Maggini J, Mirkin G, Bognanni I, Holmberg J, Piazzón IM, Nepomnaschy I, Costa H, Cañones C, Raiden S, Vermeulen M. Mouse bone marrow-derived mesenchymal stromal cells turn activated macrophages into a regulatorylike profile. PLoS One. 2010;5(2):e9252.

255. Kyurkchiev D, Bochev I, Ivanova-Todorova E, Mourdjeva M, Oreshkova T, Belemezova K, Kyurkchiev S. Secretion of immunoregulatory cytokines by mesenchymal stem cells. World journal of stem cells. 2014;6(5):552.

256. Wang X, Wang Y, Gou W, Lu Q, Peng J, Lu S. Role of mesenchymal stem cells in bone regeneration and fracture repair: a review. Int Orthop. 2013; 37(12):2491-8.

257. Abumaree $M, A$ I Jumah M, Kalionis B, Jawdat D, Al Khaldi A, Abomaray F, Fatani A, Chamley L, Knawy B. Human placental mesenchymal stem cells (pMSCs) play a role as immune suppressive cells by shifting macrophage differentiation from inflammatory $\mathrm{M} 1$ to anti-inflammatory $\mathrm{M} 2$ macrophages. Stem Cell Rev Rep. 2013;9(5):620-41.

258. Cho D-I, Kim MR, Jeong H-Y, Jeong HC, Jeong MH, Yoon SH, Kim YS, Ahn Y Mesenchymal stem cells reciprocally regulate the $M 1 / M 2$ balance in mouse bone marrow-derived macrophages. Exp Mol Med. 2014;46(1):e70.

259. François M, Romieu-Mourez R, Li M, Galipeau J. Human MSC suppression correlates with cytokine induction of indoleamine 2, 3dioxygenase and bystander M2 macrophage differentiation. Mol Ther. 2012;20(1):187-95

260. Xu L, Zhou J, Liu J, Liu Y, Wang L, Jiang R, Diao Z, Yan G, Pèault B, Sun $H$. Different angiogenic potentials of mesenchymal stem cells derived from umbilical artery, umbilical vein, and Wharton's jelly. Stem Cells Int. 2017;2017:3175748 
261. Rashedi I, Gómez-Aristizábal A, Wang XH, Viswanathan S, Keating A. TLR3 or TLR4 activation enhances mesenchymal stromal cell-mediated Treg induction via notch signaling. Stem Cells. 2017;35(1):265-75.

262. Sallustio F, Curci C, Stasi A, De Palma G, Divella C, Gramignoli R, Castellano G, Gallone A, Gesualdo L. Role of toll-like receptors in actuating stem/ progenitor cell repair mechanisms: different functions in different cells. Stem Cells Int. 2019;2019.

263. Waterman RS, Tomchuck SL, Henkle SL, Betancourt AM. A new mesenchymal stem cell (MSC) paradigm: polarization into a proinflammatory MSC1 or an immunosuppressive MSC2 phenotype. PLoS One. 2010;5(4):e10088.

264. Shirjang S, Mansoori B, Solali S, Hagh MF, Shamsasenjan K. Toll-like receptors as a key regulator of mesenchymal stem cell function: an up-to-date review. Cell Immunol. 2017;315:1-10.

265. Tomchuck SL, Zwezdaryk KJ, Coffelt SB, Waterman RS, Danka ES, Scandurro AB. Toll-like receptors on human mesenchymal stem cells drive their migration and immunomodulating responses. Stem Cells. 2008;26(1):99-107.

266. Zhao L, Hantash BM: TGF- $\beta 1$ regulates differentiation of bone marrow mesenchymal stem cells. In: Vitamins \& hormones. Volume 87, edn.: Elsevier; 2011: 127-141.

267. Lin GL, Hankenson KD. Integration of BMP, Wnt, and notch signaling pathways in osteoblast differentiation. J Cell Biochem. 2011;112(12): 3491-501.

268. Almalki SG, Agrawal DK. Effects of matrix metalloproteinases on the fate of mesenchymal stem cells. Stem Cell Res Ther. 2016;7(1):129.

269. Amable PR, Teixeira MVT, Carias RBV, Granjeiro JM, Borojevic R. Protein synthesis and secretion in human mesenchymal cells derived from bone marrow, adipose tissue and Wharton's jelly. Stem Cell Res Ther. 2014;5(2):53.

270. Ochi H, Hara Y, Tagawa M, Shinomiya K, Asou Y. The roles of TNFR1 in lipopolysaccharide-induced bone loss: dual effects of TNFR1 on bone metabolism via osteoclastogenesis and osteoblast survival. J Orthop Res. 2010;28(5):657-63.

271. Abbas S, Zhang Y-H, Clohisy JC, Abu-Amer Y. Tumor necrosis factor-a inhibits pre-osteoblast differentiation through its type-1 receptor. Cytokine. 2003;22(1-2):33-41.

272. Luo G, Li F, Li X, Wang ZG, Zhang B. TNF-a and RANKL promote osteoclastogenesis by upregulating RANK via the NF-kB pathway. Mol Med Rep. 2018;17(5):6605-11.

273. Ghali O, Chauveau C, Hardouin P, Broux O, Devedjian JC. TNF-a's effects on proliferation and apoptosis in human mesenchymal stem cells depend on RUNX2 expression. J Bone Miner Res. 2010;25(7):1616-26.

274. Wahl EC, Aronson J, Liu L, Fowlkes JL, Thrailkill KM, Bunn RC, Skinner RA, Miller MJ, Cockrell GE, Clark LM. Restoration of regenerative osteoblastogenesis in aged mice: modulation of TNF. J Bone Miner Res. 2010;25(1):114-23.

275. Ye X, Huang H, Zhao N, Zhang J, Yang P. Inhibition of Runx2 signaling by TNF-a in ST2 murine bone marrow stromal cells undergoing osteogenic differentiation. In Vitro Cellular Developmental Biol Animal. 2016;52(10): 1026-33.

276. Wang N, Zhou Z, Wu T, Liu W, Yin P, Pan C, Yu X. TNF-a-induced NF-kB activation upregulates microRNA-150-3p and inhibits osteogenesis of mesenchymal stem cells by targeting $\beta$-catenin. Open Biol. 2016;6(3): 150258

277. Moorer MC, Riddle RC. Regulation of osteoblast metabolism by Wnt signaling. Endocrinol Metab. 2018;33(3):318-30.

278. Ge L, Cui Y, Liu B, Yin X, Pang J, Han J. ERa and Wnt/ß-catenin signaling pathways are involved in angelicin-dependent promotion of osteogenesis. Mol Med Rep. 2019;19(5):3469-76.

279. Bennett CN, Longo KA, Wright WS, Suva LJ, Lane TF, Hankenson KD, MacDougald OA. Regulation of osteoblastogenesis and bone mass by Wnt10b. Proc Natl Acad Sci. 2005;102(9):3324-9.

280. Kang S, Bennett CN, Gerin I, Rapp LA, Hankenson KD, MacDougald OA. Wnt signaling stimulates osteoblastogenesis of mesenchymal precursors by suppressing CCAAT/enhancer-binding protein a and peroxisome proliferator-activated receptor $\gamma$. J Biol Chem. 2007;282(19):14515-24.

281. Herman S, Krönke G, Schett G. Molecular mechanisms of inflammatory bone damage: emerging targets for therapy. Trends Mol Med. 2008;14(6):245-53.

282. English K, Barry FP, Field-Corbett CP, Mahon BP. IFN- $\gamma$ and TNF-a differentially regulate immunomodulation by murine mesenchymal stem cells. Immunol Lett. 2007;110(2):91-100.
283. Regulski MJ. Mesenchymal stem cells: "guardians of inflammation". Wounds. 2017;29(1):20-7.

284. Marupanthorn K, Tantrawatpan C, Kheolamai P, Tantikanlayaporn D, Manochantr S. Bone morphogenetic protein-2 enhances the osteogenic differentiation capacity of mesenchymal stromal cells derived from human bone marrow and umbilical cord. Int J Mol Med. 2017;39(3):654-62.

285. Tsuji K, Bandyopadhyay A, Harfe BD, Cox K, Kakar S, Gerstenfeld L, Einhorn T, Tabin CJ, Rosen V. BMP2 activity, although dispensable for bone formation, is required for the initiation of fracture healing. Nat Genet. 2006;38(12):1424-9.

286. Tsuji K, Cox K, Gamer L, Graf D, Economides A, Rosen V. Conditional deletion of BMP7 from the limb skeleton does not affect bone formation or fracture repair. J Orthop Res. 2010;28(3):384-9.

287. Lavery K, Swain P, Falb D, Alaoui-Ismaili MH. BMP-2/4 and BMP-6/7 differentially utilize cell surface receptors to induce osteoblastic differentiation of human bone marrow-derived mesenchymal stem cells. J Biol Chem. 2008;283(30):20948-58.

288. Celil AB, Campbell PG. BMP-2 and insulin-like growth factor-I mediate Osterix (Osx) expression in human mesenchymal stem cells via the MAPK and protein kinase D signaling pathways. J Biol Chem. 2005; 280(36):31353-9.

289. Behera J, Tyagi N. Exosomes: mediators of bone diseases, protection, and therapeutics potential. Oncoscience. 2018;5(5-6):181.

290. Qi X, Zhang J, Yuan H, Xu Z, Li Q, Niu X, Hu B, Wang Y, Li X. Exosomes secreted by human-induced pluripotent stem cell-derived mesenchymal stem cells repair critical-sized bone defects through enhanced angiogenesis and osteogenesis in osteoporotic rats. Int J Biol Sci. 2016;12(7):836.

291. Takeuchi R, Katagiri W, Endo S, Kobayashi T. Exosomes from conditioned media of bone marrow-derived mesenchymal stem cells promote bone regeneration by enhancing angiogenesis. PLoS One. 2019;14(11):e0225472.

292. Furuta T, Miyaki S, Ishitobi H, Ogura T, Kato Y, Kamei N, Miyado K, Higashi Y, Ochi M. Mesenchymal stem cell-derived exosomes promote fracture healing in a mouse model. Stem Cells Transl Med. 2016;5(12):1620-30.

293. Akgun I, Unlu MC, Erdal OA, Ogut T, Erturk M, Ovali E, Kantarci F, Caliskan G, Akgun Y. Matrix-induced autologous mesenchymal stem cell implantation versus matrix-induced autologous chondrocyte implantation in the treatment of chondral defects of the knee: a 2-year randomized study. Arch Orthop Trauma Surg. 2015;135(2):251-63.

294. Chen X, Zhang F, He X, Xu Y, Yang Z, Chen L, Zhou S, Yang Y, Zhou Z, Sheng $W$. Chondrogenic differentiation of umbilical cord-derived mesenchymal stem cells in type I collagen-hydrogel for cartilage engineering. Injury. 2013;44(4):540-9.

295. Liu Y, Mu R, Wang S, Long L, Liu X, Li R, Sun J, Guo J, Zhang X, Guo J. Therapeutic potential of human umbilical cord mesenchymal stem cells in the treatment of rheumatoid arthritis. Arthritis Research Therapy. 2010;12(6):R210

296. Chen K, Wang D, Du WT, Han Z-B, Ren H, Chi Y, Yang SG, Zhu D, Bayard F, Han ZC. Human umbilical cord mesenchymal stem cells hUC-MSCs exert immunosuppressive activities through a PGE2-dependent mechanism. Clin Immunol. 2010;135(3):448-58.

297. Jorgensen C, Noel D. Mesenchymal stem cells in osteoarticular diseases: an update; 2012.

298. Jackson MT, Moradi B, Smith MM, Jackson CJ, Little CB. Activation of matrix metalloproteinases 2, 9, and 13 by activated protein $C$ in human osteoarthritic cartilage chondrocytes. Arthritis Rheumatol. 2014;66(6):1525-36.

299. Lemos DR, Duffield JS. Tissue-resident mesenchymal stromal cells: Implications for tissue-specific antifibrotic therapies. Sci Transl Med. 2018; 10(426):eaan5174

300. Cosenza S, Ruiz M, Maumus M, Jorgensen C, Noël D. Pathogenic or therapeutic extracellular vesicles in rheumatic diseases: role of mesenchymal stem cell-derived vesicles. Int J Mol Sci. 2017;18(4):889.

301. Tao S-C, Yuan T, Zhang Y-L, Yin W-J, Guo S-C, Zhang C-Q. Exosomes derived from miR-140-5p-overexpressing human synovial mesenchymal stem cells enhance cartilage tissue regeneration and prevent osteoarthritis of the knee in a rat model. Theranostics. 2017;7(1):180

302. Wang Y, Yu D, Liu Z, Zhou F, Dai J, Wu B, Zhou J, Heng BC, Zou XH, Ouyang $\mathrm{H}$. Exosomes from embryonic mesenchymal stem cells alleviate osteoarthritis through balancing synthesis and degradation of cartilage extracellular matrix. Stem Cell Res Ther. 2017;8(1):1-13. 
303. Zhu H, Ji J, Fu T, Yang J, Gu Z: SAT0057 the effect of exosomes from bone marrow mesenchymal stem cells on osteoarthritis. In: BMJ Publishing Group Ltd; 2018.

304. Puetzer JL, Petitte JN, Loboa EG. Comparative review of growth factors for induction of three-dimensional in vitro chondrogenesis in human mesenchymal stem cells isolated from bone marrow and adipose tissue. Tissue Eng B Rev. 2010;16(4):435-44.

305. Lee WY-W, Wang B. Cartilage repair by mesenchymal stem cells: clinical trial update and perspectives. J Orthopaedic Translation. 2017;9:76-88.

306. Lee HL, Yu B, Deng P, Wang CY, Hong C. Transforming growth factor- $\beta$ induced KDM4B promotes chondrogenic differentiation of human mesenchymal stem cells. Stem Cells. 2016;34(3):711-9.

307. de Kroon LM, Narcisi R, Davidson ENB, Cleary MA, van Beuningen HM, Koevoet WJ, van Osch GJ, van der Kraan PM. Activin receptor-like kinase receptors ALK5 and ALK1 are both required for TGFB-induced chondrogenic differentiation of human bone marrow-derived mesenchymal stem cells. PLoS One. 2015;10(12):e0146124.

308. Kang S-W, Do H-J, Han I-B, Shin D-A, Kim HO, Kim J-H, Lee S-H. Increase of chondrogenic potentials in adipose-derived stromal cells by co-delivery of type I and type || TGF $\beta$ receptors encoding bicistronic vector system. J Control Release. 2012;160(3):577-82.

309. Luo S, Shi Q, Zha Z, Yao P, Lin H, Liu N, Wu H, Sun S. Inactivation of Wnt/ $\beta$ catenin signaling in human adipose-derived stem cells is necessary for chondrogenic differentiation and maintenance. Biomed Pharmacother. 2013;67(8):819-24.

310. Jeong SY, Kim DH, Ha J, Jin HJ, Kwon SJ, Chang JW, Choi SJ, Oh W, Yang YS Kim G. Thrombospondin-2 secreted by human umbilical cord blood-derived mesenchymal stem cells promotes chondrogenic differentiation. Stem Cells. 2013;31(10):2136-48

311. Jeong SY, Ha J, Lee M, Jin HJ, Kim DH, Choi SJ, Oh W, Yang YS, Kim JS, Kim BG. Autocrine action of thrombospondin-2 determines the chondrogenic differentiation potential and suppresses hypertrophic maturation of human umbilical cord blood-derived mesenchymal stem cells. Stem Cells. 2015; 33(11):3291-303.

312. Freitag J, Bates D, Boyd R, Shah K, Barnard A, Huguenin L, Tenen A. Mesenchymal stem cell therapy in the treatment of osteoarthritis: reparative pathways, safety and efficacy-a review. BMC Musculoskelet Disord. 2016; 17(1):230.

313. Zhang J, Dong S, Sivak WN, Sun HB, Chang P. Stem cells in cartilage diseases and repair 2018. Stem Cells Int. 2018;2018:3672890.

314. Mosna F, Sensebe L, Krampera M. Human bone marrow and adipose tissue mesenchymal stem cells: a user's guide. Stem Cells Dev. 2010; 19(10):1449-70

315. Bifari F, Pacelli L, Krampera M. Immunological properties of embryonic and adult stem cells. World J Stem Cells. 2010;2(3):50.

316. Li Y, Chen J, Zhang CL, Wang L, Lu D, Katakowski M, Gao Q, Shen LH, Zhang J, Lu M. Gliosis and brain remodeling after treatment of stroke in rats with marrow stromal cells. Glia. 2005;49(3):407-17.

317. Sadat S, Gehmert S, Song Y-H, Yen Y, Bai X, Gaiser S, Klein H, Alt E. The cardioprotective effect of mesenchymal stem cells is mediated by IGF-I and VEGF. Biochem Biophys Res Commun. 2007;363(3):674-9.

318. Hwang JH, Shim SS, Seok OS, Lee HY, Woo SK, Kim BH, Song HR, Lee JK, Park YK. Comparison of cytokine expression in mesenchymal stem cells from human placenta, cord blood, and bone marrow. J Korean Med Sci. 2009;24(4):547-54.

319. Hwa Cho H, Bae YC, Jung JS. Role of toll-like receptors on human adiposederived stromal cells. Stem Cells. 2006;24(12):2744-52.

320. He X, Bai H, Yang G, Xue Y, Su Y. Expression of Toll-like receptors in human bone marrow mesenchymal stem cells. Zhongguo Shi Yan Xue Ye Xue Za Zhi. 2009;17(3):695-9.

321. Berk LCvd, Jansen BJ, Siebers-Vermeulen KG, Netea MG, Latuhihin T, Bergevoet S, Raymakers RA, Kögler G, Figdor CC, Adema GJ: Toll-like receptor triggering in cord blood mesenchymal stem cells. J Cell Mol Med 2009, 13(9b):3415-3426.

322. Raicevic G, Najar M, Stamatopoulos B, De Bruyn C, Meuleman N, Bron D, Toungouz M, Lagneaux $L$. The source of human mesenchymal stromal cells influences their TLR profile as well as their functional properties. Cell Immunol. 2011;270(2):207-16.
323. Jafari $M$, Asghari A, Delbandi A-A, Jalessi M, Jazayeri MH, Samarei $R$, Tajik N. Priming TLR3 and TLR4 in human adipose-and olfactory mucosa-derived mesenchymal stromal cells and comparison of their cytokine secretions. Cytotechnology. 2020:1-12.

\section{Publisher's Note}

Springer Nature remains neutral with regard to jurisdictional claims in published maps and institutional affiliations. 